\title{
Isotope and chemical microsampling: Constraints on the history of an S-type rhyolite, San Vincenzo, Tuscany, Italy
}

\author{
S. N. Felostein, A. N. Halliday, G. R. Davies, ${ }^{*}$ and C. M. Hall \\ University of Michigan, Department of Geological Sciences, 1006 C. C. Little Building, Ann Arbor, MI 48109-1063, USA
}

(Received November 9. 1992: accepted in revised form August 26, 1993)

\begin{abstract}
Fine scale heterogeneities in strontium isotope ratios, ${ }^{40} \mathrm{Ar}-{ }^{39} \mathrm{Ar}$ ages, and chemical composition have been determined for individual mineral grains and enclaves in the rhyolites of San Vincenzo, Italy. The rhyolites are peraluminous with phenocrysts of alkali feldspar, plagioclase, biotite, and cordierite and have previously been divided into two groups on the hasis of whole rock major element chemistry. Group B lavas are distinguished from Group A in having higher $\mathrm{MgO}$ and $\mathrm{CaO}$ contents as well as containing two pyroxenes and chilled latite enclaves. The Group B lavas show textural evidence for disequilibrium, such as resorption and sieve zones in feldspars. Laser fusion ${ }^{40} \mathrm{Ar}-{ }^{39} \mathrm{Ar}$ dating of individual alkali feldspar crystals suggests that the eruption of these rhyolites took place $4.38 \pm 0.04 \mathrm{Ma}$, although small amounts of excess argon are present in subhedral and cloudy crystals. The groundmass in the Group A sample has a higher initial ${ }^{87} \mathrm{Sr} /{ }^{86} \mathrm{Sr}(0.725)$ than that of the Group $\mathrm{B}(0.713)$. The $\mathrm{Sr}$ isotope compositions of chemically and texturally characterized individual grains reveal marked disequilibrium between minerals and the host glass as well as within-grain zonation. The feldspars and coarsc-graincd biotites have initial ${ }^{87} \mathrm{Sr} /{ }^{86} \mathrm{Sr}$ that are intermediate between those of the Group A and B glasses, with alkali feldspar generally having higher initial ${ }^{87} \mathrm{Sr} /{ }^{86} \mathrm{Sr}$ ratios than plagioclase. Chilled latite enclaves, which are present in only the Group B lavas, have relatively low initial ${ }^{87} \mathrm{Sr} /{ }^{86} \mathrm{Sr}$ ratios in the range $0.7082-0.7088$. The mineral chemistry and isotope data indicate that restite does not form a significant portion of the crystalline assemblage and, therefore, cannot be the source of the strontium isotope disequilibrium. Xenocrysts mixed into the rhyolite from a mafic magma were identified as clinopyroxene megacrysts, clinopyroxene-orthopyroxene clots, orthopyroxene-plagioclase clots, and plagioclase with extensive sieve textures. These grains all have relatively low initial ${ }^{87} \mathrm{Sr} /{ }^{86} \mathrm{Sr}$ ratios. Other grains that may be xenocrysts are cordierites with cores containing inclusions of biotite, spinel, and sillimanite, and alkali feldspars with excess ${ }^{40} \mathrm{Ar}$. The strontium isotope disequilibrium in phenocrysts of plagioclase, alkali feldspar, and biotite is attributed to a changing melt chemistry that was too rapid for strontium diffusive equilibration. A model for the San Vincenzo magma chamber is proposed in which the Sr isotope evolution of the Group B rhyolites is due to magma mixing of a crustal melt with latite magma containing unradiogenic strontium. The variable initial strontium isotope compositions of Group A phenocrysts may be due to assimilation or crystallization along the interface between mingled Group A and B magmas.
\end{abstract}

\section{INTRODUCTION}

MANY SILICIC IGNEOUS rocks contain mineral grains that preserve disequilibrium textures, indicating that multiple components or processes may be involved in their petrogenesis. A wide range of models has been proposed regarding these textures and the role of restite, assimilation, and magma mixing in the genesis of silicic magmas (e.g., CHAPPELL et al., 1987; WALl. et al., 1987). The traditional geochemical approach to unraveling the petrogenesis of silicic magmas has been to use the compositions of bulk samples as integrated indications of mass transfer and differentiation processes. This approach is limited in its ability to determine exact origins of individual mincral grains and only provides an average geochemical signature for what may be a multitude of complex processes. We take a different approach in this study of a peraluminous rhyolite near San Vincenzo, Italy. We have

* Present address: Faculteit der Aardwetenschappen, Vrije Universiteit, De Boelelaan 1085, 1081 HV Amsterdam, Netherlands. analyzed individual mineral grains and subzones within grains for strontium isotope composition. For each of the grains used for isotope analysis, textural information, and electron microprobe analyses were obtained, thus permitting correlation between petrographic observations and isotopic data. We find evidence of striking isotopic disequilibrium between individual mineral grains and the glass as well as withincrystal Sr isotope zonation. The combined isotopic and petrographic data are used to interpret the genesis of each grain, i.e., whether restite, xenocryst, or phenocryst. A restite (residual source material after partial melting) or xenocryst origin is frequently invoked to explain observed isotopic disequilibrium among mineral separates and glass. We will show that the strontium isotope disequilibrium at San Vincenzo can result from crystal growth in a liquid of rapidly changing isotopic composition, and that a significant restite or xenocryst population is not needed to explain the disequilibrium. We envision a magma chamber in which systematic isotopic heterogeneities in the melt result from the processes of magma mixing and assimilation. Stratification in the magma chamber prevents thorough mixing, resulting in different isotopic signatures for different lavas from the same magma chamber. 


\section{THE SAN VINCENZO RHYOLITES}

The rhyolites of San Vincenzo are located in the Tuscan magmatic province, Italy (Fig. 1), a region dominated by crustal anatectic melts (TAYLOR and TUR1, 1976; PECCERILlO et al., 1987). However, mixing between crustal melts and high-K Roman-type melts has been identified in several Tuscan lavas, such as at Mt. Amiata and Mt. Cimini (TAYLOR and TURI, 1976; POLI et al., 1984). Igneous activity has occurred in this region over the last $8 \mathrm{Ma}$ (BARBERI, 1971). The San Vincenzo center has yielded a range of ages using a variety of isotopic techniques (2.82-7.60 Ma: FERRARA et al., 1989) but has been assumed to be about $4.7 \mathrm{Ma}$, based on K-Ar dating of biotite (BORSI et al., 1967). The center covers an area of roughly $10 \mathrm{~km}^{2}$ and is composed of lavas, including a highly altered volcanic unit. extruded onto Liguride limestone. Underlying the limestone are mica schists, gneiss, and amphibolite of Hercynian age (GIANELLI and PuXeddu, 1979; Del MORO et al., 1982). Other broadly coeval rocks in this area include the $5.7 \mathrm{Ma}$ Botro ai Marmi monzogranite (BorsI et al., 1967), $5 \mathrm{~km}$ south of San Vincenzo, and the Campiglia porphyry dikes, $5-10 \mathrm{~km}$ south and east of San Vincenzo. Geothermal activity is found about $25 \mathrm{~km}$ northeast of San Vincenzo in the Larderello fields.

On the basis of phenocryst assemblages, MARINELLI (1961) and BARBFRI ( 1967 ) proposed that the San Vincenzo rhyolites were derived from partial melting of metapsammites. Further support for a crustal origin has come from trace element modeling (DUPUY and ALLĖGRE, 1972; GIRAUD et al., 1986), and radiogenic ( $\mathrm{Sr}, \mathrm{Nd}$, and $\mathrm{Pb}$ ) and oxygen isotope studies (FERRARA, 1969; TAYLOR and TURI, 1976: VOLLMER, 1976, 1977). Trace element modeling of whole rock and mineral separates has suggested that the glass represents the residual liquid after crystal growth (GIRAUD et al., 1986). PINARELLI et al. (1989), however, argued that whole rock trace element and $\mathrm{Sr}$ isotope data document mixing of crust and mantle melts. FERRARA (1983) and FERRARA et al. (1986, 1989), using whole rock and bulk mineral separates, documented strontium isotope disequilibrium between glass, alkali feldspar, plagioclase, biotite, and cordierite. They interpreted the isotopic disequilibrium in terms of several processes. They consider plagioclase as well as biotite and cordierite to be prevalently restite, with a portion of the biotite representing xenocrysts from the latite. Another source they proposed for the isotopic disequilibrium is preferential migration of radiogenic strontium during crustal melting. In addition, they suggested that late-stage contami- nation hy latite in some lavas resulted in isotopic disequilibrium between glass and alkali feldspar and plagioclase. However, all of the previous work used bulk mineral separates to model the origin of the rhyolites. We have analyzed only a subset of the samples used by these authors, but we have obtained isotopic compositions for individual mineral grains and subzones within grains rather than bulk mincral scparates in an effort to distinguish among these possible sources of disequilibrium. In addition, while some sample localities are oxidized, altered, and/or contain secondary mineralization, we have limited our study to two localities that are absolutely fresh, being glassy and showing no evidence for oxidation or secondary mineralization. This eliminates any question as to whether the isotopic disequilibrium is the result of secondary processes.

Whole-rock major element compositions of the rhyolites have been presented by Giraud (1986), Ferrara (1989), and Pinarelli et al. (1989). Matrix glass analyses of the samples analyzed here are given in the Appendix. The rhyolites, $69-70 \mathrm{wt} \% \mathrm{SiO}_{2}$, have between $2-4 \%$ normative corundum; the peraluminous index $\mathrm{A} / \mathrm{CNK}\{\mathrm{mol} \%$ $\left.\mathrm{Al}_{2} \mathrm{O}_{3} /\left(\mathrm{CaO}+\mathrm{Na}_{2} \mathrm{O}+\mathrm{K}_{2} \mathrm{O}\right)\right\}$ is greater than one. These last two characteristics, as well as the presence of cordierite phenocrysts, support their identification as S-type lavas (CHAPPELL and WHITE, 1974). The lavas are divided into two groups, $A$ and $B$, on the basis of their major element chemistry (FERRARA et al., 1989). Whole rock compositions of Group B lavas have higher $\mathrm{MgO}$ and $\mathrm{CaO}$ contents and are less peraluminous than Group A lavas, although these differences are not evident in the glasses. Whole rock and glass compositions are shown on an $\mathrm{A}^{\prime} \mathrm{KF}$ plot $\left\{\mathrm{A}^{\prime}\left(\mathrm{Al}_{2} \mathrm{O}_{3}-\mathrm{Na}_{2} \mathrm{O}-\mathrm{K}_{2} \mathrm{O}-\mathrm{CaO}\right)-\mathrm{K}\left(\mathrm{K}_{2} \mathrm{O}\right)\right.$ $\mathrm{F}\left(\mathrm{FeO}_{T}+\mathrm{MgO}\right\}$ (Fig. 2). Examples of peraluminous S-type granites and rhyolites from the Lachlan fold belt, Australia are plotted for comparison (WYBORN et al., 1981: WHITE and CHAPPELL, 1988; Fig, 2). The Group A and B lavas of San Vincenzo have higher alkali content and lower $\left(\mathrm{FeO}_{T}+\mathrm{MgO}\right)$ than these peraluminous magmas. Relevant experimentally produced liquid compositions also are shown. These liquids were generated by fluid-absent dehydration melting, e.g.. biotite + quartz + plagioclase + aluminosilicate $=$ melt + garnet \pm K-feldspar (GKLEN, 1976; CLEMENS and WALL, 1981; VIELZEUF and HOLLOWAY, 1988; LE BRETON and THOMPSON, 1988). The whole rock major element chemistry of San Vincenzo is similar to these liquids. Chilled magmatic enclaves from the Group B lavas analyzed by FerRARA et al. (1989) have $60 \mathrm{wt} \% \mathrm{SiO}_{2}, 4 \mathrm{wt} \%$ $\mathrm{K}_{2} \mathrm{O}$, and $14-18 \%(N=2)$ normative quartz; they are classified as latites.

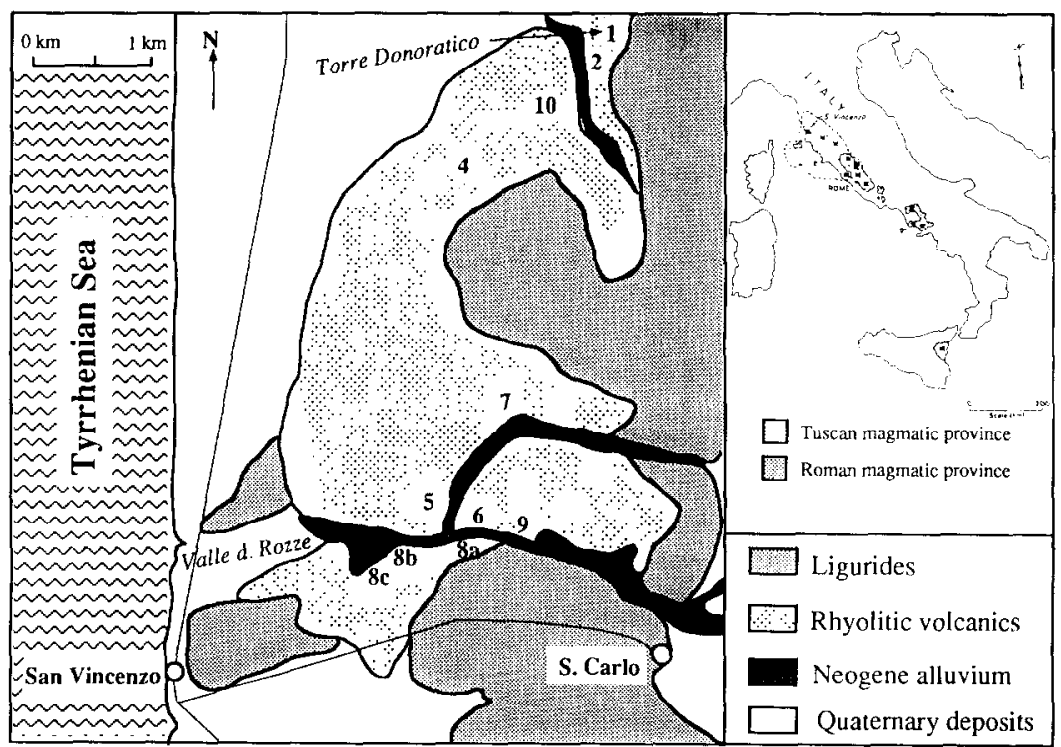

FIG. 1. A geologic map of the San Vincenzo region with sample locations. The two samples used for detailed study are samples 1 (Group B) and $8 \mathrm{~b}$ (Group A). The map of Italy shows the location of San Vincenzo and the Tuscan and Roman magmatic provinces. After TAYLOR and TURI (1976) and FERRARA et al. (1989). 


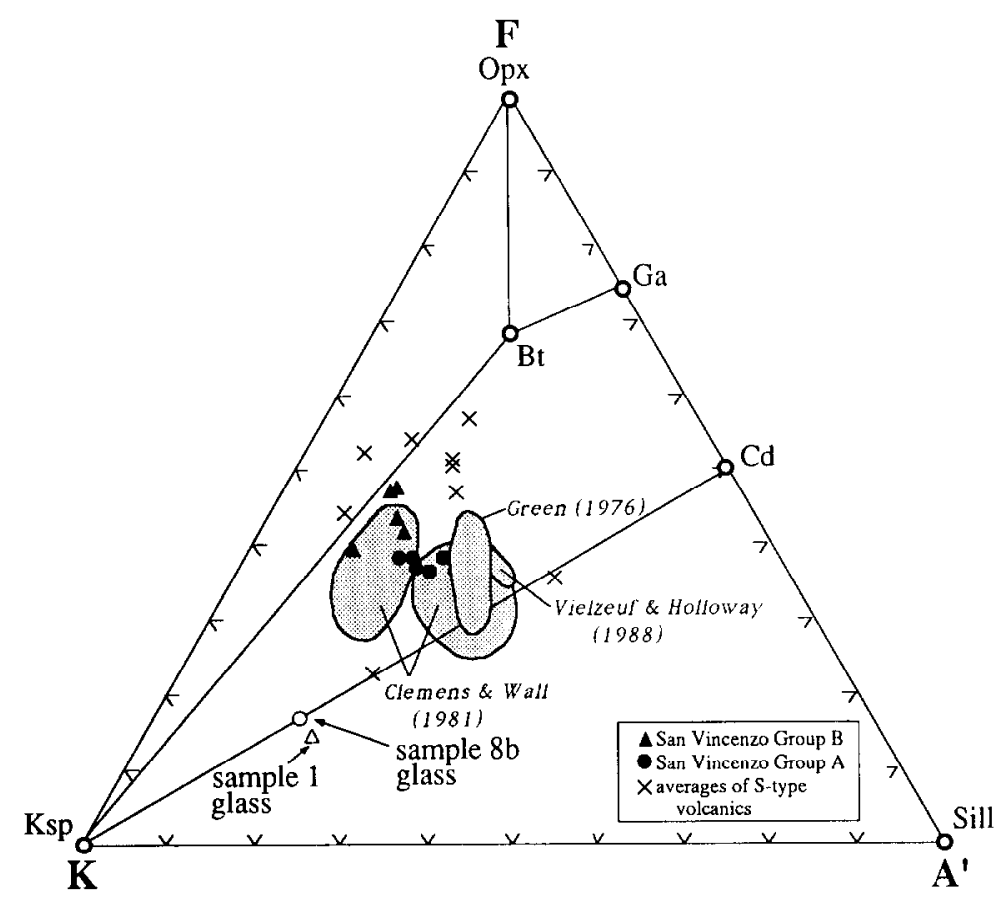

FiG. 2. $\mathrm{A}^{\prime}\left(\mathrm{Al}_{2} \mathrm{O}_{3}-\mathrm{Na}_{2} \mathrm{O}-\mathrm{K}_{2} \mathrm{O}-\mathrm{CaO}\right)-\mathrm{K}\left(\mathrm{K}_{2} \mathrm{O}\right)-\mathrm{F}\left(\mathrm{FeO}_{T}+\mathrm{MgO}\right)$ plot in mole percent for whole rock Group $\mathrm{A}$ and $\mathrm{B}$ San Vincenzo lavas. Experimental glass compositions are from GREEN (1976); CLEMENS and WALL ( 1981 ); VIELZEUF and HOLLOWAY (1988). Data for Australian S-type volcanics are an average of each pluton: WYBORN et al. (1981); White and CHAPPELL (1988). Whole rock data for San Vincenzo are from FerRARA et al. (1989) and glass data are from this study. Abbreviations are same as used in Table 2. After PICHAVANT et al. (1988).

\section{METHODS}

Samples were collected from eleven locations (Fig. 1). On the basis of their varied phenocryst, xenocryst, and enclave population, samples from two locations were selected for detailed study: sample $8 b$ is from Group A, while sample 1 is from Group B (hereafter simply referred to as sample from Group A or Group B). They are glassy and unaltered, showing no oxidation or secondary mineralization, and little hydration. Other sample locations either had some of these alteration characteristics or were of a highly altered unit. Previous work in San Vincenzo has included many of the sample sites we excluded due to alteration (FERrara et al., 1989; Pinarelli et al. 1989), while others do not indicate sample locations (FERRARA, 1969. 1983; DUPUY and ALLÈGRE, 1972; VOLLMER, 1976, 1977; Giraud et al., 1986). Multiple thin sections were examined for both samples $8 \mathrm{~b}$ and 1 . Strontium isotope analyses of individual mineral grains were performed to identify possible isotopic differences within a population not evident in bulk mineral analyses. Two methods were used to sample individual crystals. In the first, the rock was crushed in a jawcrusher. Single mineral grains that had been cleanly dislodged from the glass matrix and had retained complete crystal form were picked under a binocular microscope. Crystals were analyzed on the electron microprobe and each was subsequently crushed in acetone and the inclusions (apatite inclusions in biotite, and biotite in cordierite) removed. Each mineral grain was then individually dissolved and analyzed for strontium isotope compositions. Feldspars were chosen to represent a spectrum of crystal morphologies (Type 1: euhedral and clear, these grains formed a narrow range size, all approximately $1.5 \mathrm{~mm} \times 1.5 \mathrm{~mm} \times 0.5 \mathrm{~mm}$; Type 2 : euhedral with some jagged edges, clear; Type 3 : slightly rounded and light yellow in color: Type 4: white, friable, anhedral; Type 5: rounded and slightly milky; Type 6: large cloudy subhedral grains), and weighing between 0.7 and $9.1 \mathrm{mg}$. This method was also used to sample biotite (1.3$5.4 \mathrm{mg}$ ) and cordierite ( $1.3-10.1 \mathrm{mg}$ ). In the second method, used for feldspars and latite enclaves only, a dentist drill with a $0.5 \mathrm{~mm}$ diameter mandrel extracted sample from individual grains from a thin section chip. The drilling produced a powder $(<0.4 \mathrm{mg})$ that was dissolved for isotopic analyses. Some microscopic inclusions, however, could not be avoided with this method, so drilling depth was shalluw in order to minimize this source of error. Subsequently, thin sections were made from the rock chip and mineral chemistry determined on the remainder of the drilled crystals. Grains that exhibited disequilibrium textures or characteristics often regarded as indications of a restite or xenocryst origin were targeted (VERNON, 1983; ChAPPELl et al., 1987; WALl et al., 1987). In addition, a few core and rim samples from single crystals were obtained using the drill.

Major element mineral compositions were obtained with the Cameca Camebax electron microprobe at the University of Michigan using $15 \mathrm{kV}$ accelerating voltage and $10 \mathrm{nA}$ beam current. Glass analyses were obtained at $5 \mathrm{nA}$ using variable counting times and rastering over a $3 \mu \mathrm{m}^{2}$ area. The strontium isotope compositions and concentrations of $\mathrm{Rb}$ and $\mathrm{Sr}$ were determined on a V.G. Sector multicollector thermal ionization mass spectrometer using the methods outlined in HALLIDAY et al. (1989). During the course of these analyses, NIST SRM987 standard gave a mean for ${ }^{87} \mathrm{Sr} /{ }^{86} \mathrm{Sr}$ of 0.710255 $\pm 22(2 \sigma, N=9)$. The accuracy of the rubidium and strontium concentrations is limited by weighing errors to approximately $1 \%$, while the parent/daughter ratios have a greater accuracy $(0.5 \%)$ due to the use of mixed ${ }^{87} \mathrm{Rb}^{84} \mathrm{Sr}$ spikes. Precision varied as a function of sample size and $\mathrm{Sr}$ concentration. Three analyses of blanks were between 90 and $100 \mathrm{pg}$ for both rubidium and strontium. A correction for strontium blank was applied to all the strontium isotopic data. At the time of these analyses, the strontium chemistry blanks were less reproducible than we normally expect. To take account of any effects this might have on the data we allowed for a large unecrtainty in the blank correction in terms of both its magnitude and isotopic composition, while using an average similar to that normally measured. This incorporated worst case uncertainty in the blank correction was negligible in most cases and is significant only in the case of biotite and cordierite (Table 2) while not limiting the interpretation of any of the data. The drill bits utilized were identical to thuse used in a previous microdrilling study (DAVIDSON et al., 1990) in which it was ascertained by dissolving and analyzing an entire drill bit that 
the strontium blank contrihution from abrading the bit would be negligible. The ${ }^{87} \mathrm{Sr} /{ }^{86} \mathrm{Sr}$ of the total blank was assumed to be 0.710 \pm 0.005 and the amount of the blank was assumed to be $100 \pm 50$ pg. These uncertainties were combined with the mass spectrometer run precisions in assigning the overall uncertainty in ${ }^{87} \mathrm{Sr} /{ }^{86} \mathrm{Sr}$ reported in Table $2 .{ }^{40} \mathrm{Ar}_{-}{ }^{39} \mathrm{Ar}$ ages were obtained from individual alkali feldspar grains using a Coherent continuous wavelength argon ion laser and a small volume gas purification system connected to an MAP 215 rare gas mass spectrometer equipped with a Nier source, Faraday detector, and a Balzers electron multiplier. Irradiations were performed in core at the University of Michigan Ford Reactor. The fusion blank of the system was monitored every third run and all sample argon isotope peaks were blank corrected. Blanks were on the order of $1.10 \times 10^{-13} \mathrm{ml} \mathrm{STP} \mathrm{for}{ }^{36} \mathrm{Ar}$ and $7.68 \times 10^{-12} \mathrm{ml}$ STP for ${ }^{40} \mathrm{Ar}$. Reported ages are based on an age of $520.4 \mathrm{Ma}$ for standard hornblende MMhb-l (SAMSON and ALEXANDER, 1987). The uncertainties in the ages include the uncertainties in the $J$-values, which are less than other sources of error.

\section{PETROGRAPHY, MINERAL CHEMISTRY, AND GEOTHERMOMETRY}

The phenocryst assemblage in San Vincenzo rhyolitic lavas is dominantly quartz, alkali feldspar, plagioclase, and biotite with lesser amounts of cordierite; apatite, epidote, monazite, ilmenite, and zircon are present as accessory phases. Groundmass phases include plagioclase, biotite, apatite, zircon, and ilmenite. Group B lavas also contain clinopyroxene megacrysts, clots of clinopyroxene-orthopyroxene and orthopyroxene-plagioclase, as well as chilled magmatic enclaves of latite composition. The sample from Group B is 69\% crystalline while that from Group $\mathrm{A}$ is $31 \%$ crystalline. Both are set in a glassy matrix, although the one from Group $B$ has considerable groundmass crystallization. Furthermore, both samples studied here are vesicle-free, and show no evidence for alteration or secondary mineralization and little hydration. Presented below and in the Appendix are representative analytical data for interstitial glasses, alkali feldspar, plagioclase, biotite, cordierite, clinopyroxene, and orthopyroxene as well as modal data from this study. Mineral chemistry also was presented by PINARELLI et al. (1989).

\section{Latite Enclaves}

Fine grained magmatic enclaves of latite composition (FERRARA et al., 1989), up to $5 \mathrm{~mm}$ diameter, are ubiquitous in all Group B lavas, including the sample location studied here; however, only one enclave has been found in a Group A lava, sample locality $8 \mathrm{a}$ (Fig. 3a). The enclaves (including the one from Group A) are characterized by calcic plagioclase with cores of $A n_{85}$ (Fig. 4) and magnesian biotite with minor amounts of clinopyroxene ( $\mathrm{WO}_{46} \mathrm{En}_{48} \mathrm{Fs}_{6}$; Fig. 5), magnetite or pyrrhotite, and apatite. One enclave was found with amphibole instead of clinopyroxene. Textures in the enclaves, such as skeletal to lath-like (plagioclase) or elongate (apatite) phenocrysts are indicative of rapid cooling (LOFGREN, 1974; BACON, 1986). These enclaves provide evidence for the interaction of a second, hotter liquid with the rhyolite magma.

\section{Alkali Feldspar}

Alkali feldspar occurs as euhedral to anhedral crystals, commonly embayed, up to $2 \mathrm{~mm}$ diameter in both the Group
A and B sample. Crystals are found with granophyric intergrowths with quartz and with inclusions of biotite and plagioclase oriented parallel to the crystal faces (Fig. 3b). These textures support a magmatic origin (WALL et al., 1987). The alkali feldspars vary significantly in composition $\left(\mathrm{Or}_{56-78}\right)$, with rim and groundmass compositions spanning the entire range (Fig. 4).

\section{Plagioclase}

Plagioclase is most commonly seen as individual euhedral to subhedral crystals up to $2 \mathrm{~mm}$ diameter, although cumulus clots of euhedral grains also are present (Fig. 3c). The compositions of plagioclase from the Group B sample span a large range, with very calcic core compositions $\left(A n_{80}\right)$ and rims and groundmass crystals in the range $\mathrm{An}_{30-60}$. Plagioclase grains in the Group A sample are generally less calcic, with core compositions up to $\mathrm{An}_{68}$ and rims and groundmass in the range $A n_{27-34}$. Resorption surfaces are common in Group $B$ but rarer in those of Group A. Discquilibrium textures such as sieve rims or cores (also referred to as honeycomb, fingerprint, spongy, and mottled textures) are observed in approximately $30 \%$ of the plagioclase in the Group B sample but only $10 \%$ in the sample from Group A. Plagioclase immediately adjacent to the sieve cores may be very calcic, i.e., $\mathrm{An}_{83}$. Figure $3 \mathrm{~d}$ is of a sieve rim from a plagioclase in the Group B sample. The core of the crystal is normally zoned $\mathrm{An}_{44-25}$; immediately following the sieve texture the plagioclase is $\mathrm{An}_{34}$. The sieve rim itself is composed of plagioclase, $\mathrm{An}_{47}$, and a glass with $74 \mathrm{wt} \% \mathrm{SiO}_{2}$ (the full glass analysis is given in the Appendix ). Rare, large (5-10 mm length) plagioclase characterized by sieve texture that encompass virtually the entire grain are found in the sample from Group B. These have calcic overgrowth rims $\left(A n_{85-80}\right)$ that are not in equilibrium with the host rhyolite (Fig. 3e). The cores of these grains are rarely preserved. Plagioclase also is found as euhedral crystals in the mafic enclaves and associated with pyroxene clots (Group B only). Crystals are normally zoned from $\mathrm{An}_{85}$ to $\mathrm{An}_{46}$.

\section{Biotite}

Two populations of biotite are recognized. Ferroan biotite is found as individual grains or as inclusions in plagioclase, cordierite, and alkali feldspar and as a groundmass phase. Groundmass crystals have $\mathrm{Mg} \#[\mathrm{Mg} /(\mathrm{Mg}+\mathrm{Fe})]$ from 0.38 $0.56, \mathrm{Al}^{\mathrm{V} \mathrm{l}}$ of $0.46-0.74$, and $\mathrm{F} /(\mathrm{F}+\mathrm{OH})$ of $0.17-0.42$. Magnesian biotite makes up a small percentage of the total biotite population. It is found as phenocrysts within the chilled mafic enclaves and is associated with clinopyroxene-orthopyroxene glomerocrysts and plagioclase with extensive sieve zones. Their $\mathrm{Mg}$ \# range from $0.56-0.78$, the $\mathrm{Al}^{\mathrm{VI}}$ from 0.17 0.33 , and $\mathrm{F} /(\mathrm{F}+\mathrm{OH})$ of $0.15-0.35$. A disequilibrium texture characterized by numerous titanian magnetite inclusions surrounded by a zone of plagioclase $\left(\mathrm{An}_{47}\right)$ or glass is frequently observed in the magnesian biotites (Fig. 3e). Similar disequilibrium textures have been observed in pelite xenoliths that have undergone partial melting in basalt (e.g., BREARLEY, 1987a) and have been produced in melting experiments of biotite (BREARLEY, 1987b). 


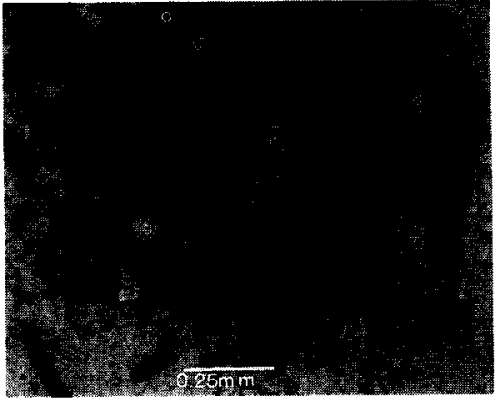

(a)

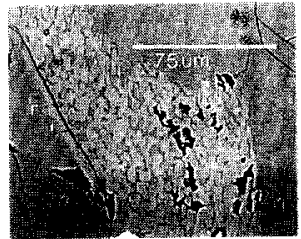

(d)

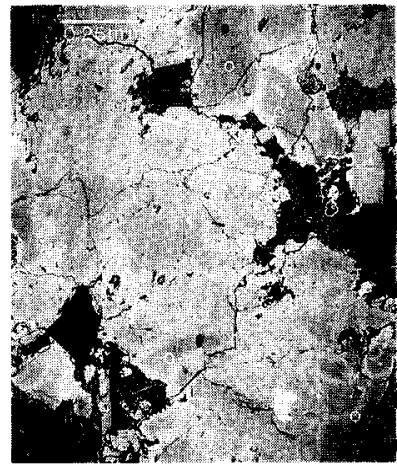

(g)

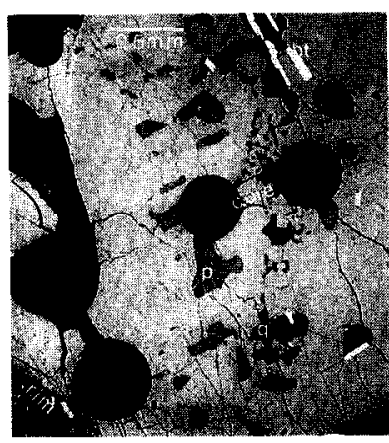

(b)

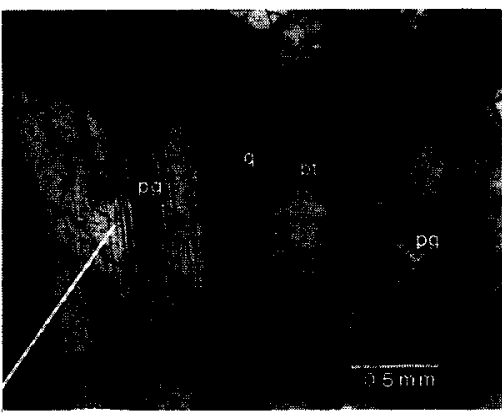

(c)

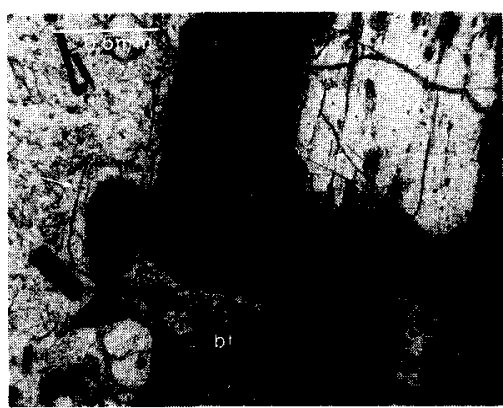

(e)

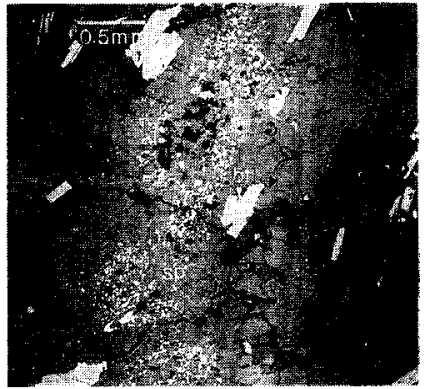

(f)

FIG . 3. (a) Backscattered electron (BSE) image of a latite enclave with high vesicularity, containing plagioclase phenocrysts (clear), elongated biotites and minor amounts of apatite and clinopyroxene (c). This enclave was analyzed for strontium isotopes (sv901-1-7 latite); the initial ${ }^{87} \mathrm{Sr} /{ }^{86} \mathrm{Sr}$ is 0.70821 . (b) BSE photo of a euhedral alkali-feldspar crystal analyzed for $\mathrm{Sr}$ isotopes (1-1-14 ksp). The core is more radiogenic than the rim $(0.7156$ vs. 0.7145$)$. The alkali feldspar is granophyric with quartz (q) and contains inclusions of biotite (bt) and plagioclase ( $p$ ). The round circles are drill core holes from $\mathrm{Sr}$ isotope microsampling. (c) Photomicrograph under crossed polars of a plagioclase crystal analyzed for $\mathrm{Sr}$ isotopes $(1-1-14 \mathrm{plg})$. The core is less radiogenic than the rim $(0.7136$ vs. 0.7144$)$. The plagioclase is part of a clot with intergrown quartz and biotite. Core to rim analyses along the traverse shown are given in Fig. 4. (d) BSE photo of sieve rimmed plagioclase. The light portion of the sieve zone is $\mathrm{An}_{47}$, while the dark portion of the sieve zone is glass. The core of the crystal is normally zoned $A n_{44-25}$ and the post-sieve rim ( $r$ ) is $\mathrm{An}_{34}$. (e) Photomicrograph under plane polarized light of a large, extensively sieve-textured plagioclase grain analyzed for strontium isotopes (1-1-4 plg 1); the initial ${ }^{87} \mathrm{Sr} /{ }^{86} \mathrm{Sr}$ is 0.70908 . The core is $\mathrm{An}_{56}$; the thin rim after the sieve $\mathrm{zone}$ is An $85-80$ (at arrow). The sieve zone is composed of calcic plagioclase and glass (analysis given in the Appendix). Associated with the plagioclase is a magnesian biotite (bt) with numerous magnetite inclusions. (f) BSE photo of a large xenocryst cordierite with numerous spinel ( $\mathrm{sp}$ ) and aluminosilicate (al) inclusions and biotite (bt). (g) BSE photo of a two-pyroxene clot. Clinopyroxene forms the majority of the clot; orthopyroxene grains are labeled $(\mathrm{o})$. The temperature calculated from adjacent cores is $1100^{\circ} \mathrm{C}$ at 5 kbars

\section{Cordierite}

Cordierite is usually euhedral and inclusion-free and shows normal and reverse zonation with $\mathrm{Mg}$ \# from $0.47-0.59$. Cordierites characterized by ovoid shapes and cores containing inclusions of sillimanite, spinel, and biotite are about $8 \%$ of the cordierite population in the sample from Group B; none were found in the sample from Group A (Fig. 3f).

\section{Pyroxene}

Several types of clinopyroxene associations are observed in Group B, including small euhedral crystals and euhedral crystals up to $5 \mathrm{~mm}$ in length (hereafter referred to as megacryst to distinguish from submillimeter-size crystals), sometimes with attached chilled liquid. The latite enclaves contain very small clinopyroxene phenocrysts, frequently degraded to biotite or more rarely to amphibole (Fig. 3a). The megacrysts and individual clinopyroxenes have similar compositions ( $\mathrm{WO}_{46} \mathrm{En}_{48} \mathrm{Fs}_{6}$, circled analyses, Fig. 5), suggesting they are liquidus phases from a single liquid. However, clinopyroxenes occurring in two enclaves have lower wollastonite contents $\left(\mathrm{Wo}_{41}\right)$. Clinopyroxene in glomerocrysts (Fig. $3 \mathrm{~g}$ ) with orthopyroxene, magnesian biotite, and plagioclase are also chemically distinct, with both the clinopyroxenc and 


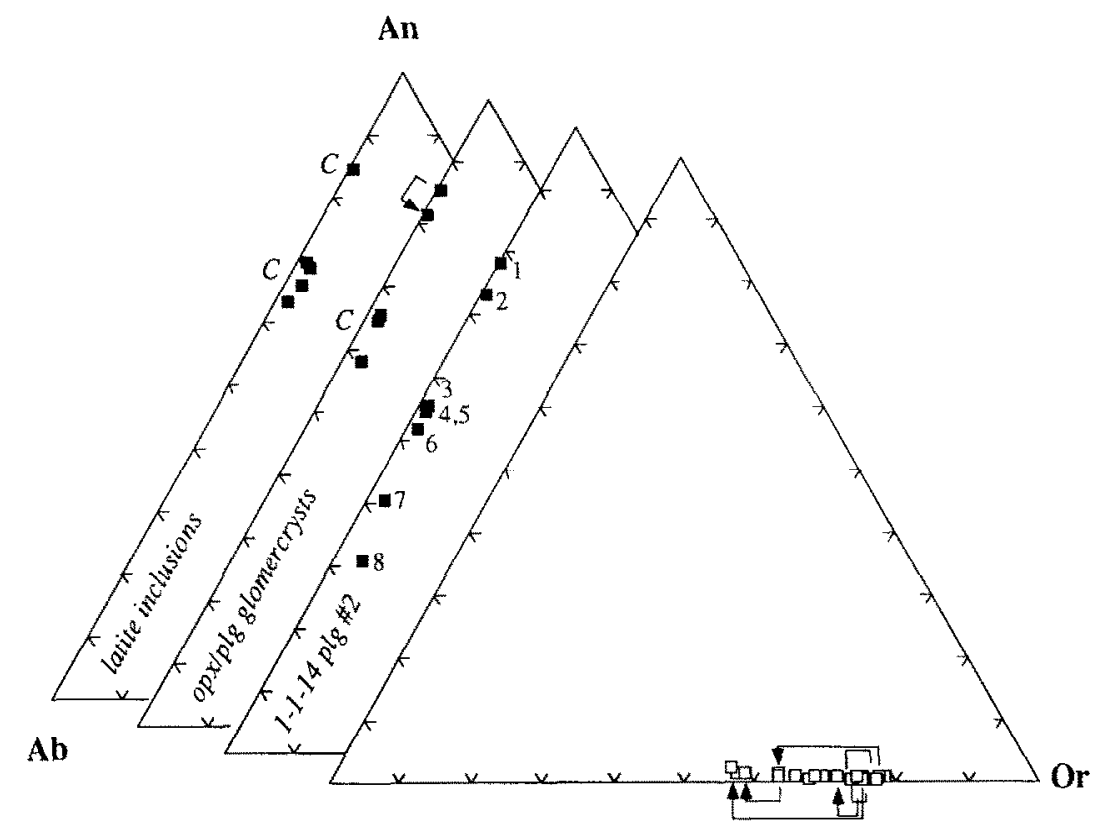

FIG. 4. Feldspar analyses from rhyolites. Plagioclase are from latite enclaves, orthopyroxene-plagioclase glomerocrysts and plagioclase grain 1-1-14 used for isotope analysis, all from the Group B sample. Numbers indicate core (1) to rim (8) analyses. Also shown are all alkali feldspar analyses from both samples. Core and rim (head of arrow) analyses for selected grains are connected.

orthopyroxene zoned to more ferrous and, for the clinopyroxene, less calcic rims. Orthopyroxene was found in one glomeroporphyritic clot with euhedral, normally zoned calcic plagioclase (cores of $\mathrm{An}_{85}$ ). The orthopyroxenes have magnesian core compositions $\left(\mathrm{WO}_{4} \mathrm{En}_{78} \mathrm{Fs}_{18}\right)$ and are normally zoned (Fig. 5). None of the Group A samples contain either clinopyroxene or orthopyroxene.

\section{Thermobarometry}

Thermobarometric models have limited applicability to San Vincenzo due to the disequilibrium present ( see discussion below), and, therefore, the temperature and pressure of crystallization of the rhyolite remains poorly constrained. However, an exception are intergrown clots of, for example, two pyroxenes or two feldspars, in which the minerals can be assumed to be in equilibrium with each other. The temperature and pressure calculated from this assemblage can,

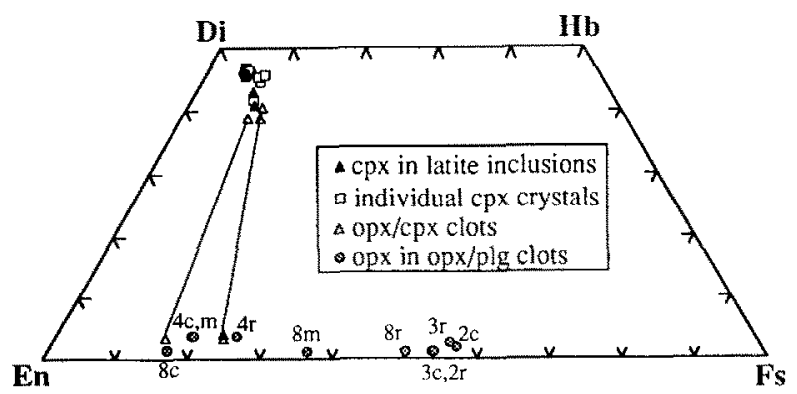

FlG. 5. Representative pyroxene compositions from the Group B sample. Core $(\mathrm{m})$, middle $(\mathrm{m})$ and $\mathrm{rim}(\mathrm{r})$ analyses are indicated for orthopyroxenes. Two pyroxenes used for temperature calculations are connected by tie lines. therefore, be used to say something about that component. The ternary feldspar thermometer of FUHRMAN and LINDSLEY (1988) was used with the revised parameters of LINDSLEY and NEKVASIL (1989) to determine temperatures of coexisting alkali feldspar and plagioclase in the rhyolite. However, two feldspars which texturally exhibit unequivocal evidence for equilibration are rare. An equilibrium temperature of $780^{\circ} \mathrm{C}$ at 2 kbars was obtained for a pair of feldspars in a clot $\left(\mathrm{An}_{35} \mathrm{Or}_{4}\right.$ and $\left.\mathrm{Or}_{75} \mathrm{~A} n_{1}\right)$. Temperatures calculated from plagioclase crystals mantled by alkali feldspar are not concordant, suggesting that the mantling process was due to disequilibrium conditions (e.g., HiBBARD, 1981). Crystallization experiments on peraluminous magmas of similar composition to San Vincenzo provide an upper limit temperature of 825 $870^{\circ} \mathrm{C}$ by the presence of biotite (CLEMENS and WALL, 1981 ). Two-oxide thermometry could not be used to obtain temperatures in the rhyolite since only one oxide is present. The two-pyroxene thermometer of LINDSLEY (1983) was used to determine temperatures of coexisting clinopyroxene and orthopyroxene found as clots in the Group B lavas. A temperature of $1100^{\circ} \mathrm{C}$ at low pressures $(2 \mathrm{~kb})$ was obtained from cores of adjacent clinopyroxene and orthopyroxene crystals (Figs. 3g, 5). The mineralogy of the latite enclaves is considered to be, for the most part, quench products, and, therefore, cannot be used to determine the temperature of the melt prior to mingling with the rhyolite liquid.

$$
{ }^{40} \mathrm{Ar}^{3{ }^{39}} \mathrm{Ar} \text { AGES }
$$

Nineteen individual alkali feldspar phenocrysts from the sample from Group B were analyzed for ${ }^{40} \mathrm{Ar}-{ }^{39} \mathrm{Ar}$ by total fusion laser analysis. Alkali feldspar grains from sample $8 \mathrm{~b}$ (Group A) were too small to analyze by this method. Ages were calculated for each grain by the use of an average 
Table $1{ }^{40} \Lambda \mathrm{r}-{ }^{39} \Lambda \mathrm{r}$ analyses alkali feldspars from Group B sample

\begin{tabular}{|c|c|c|c|c|c|c|}
\hline Sample & $\frac{{ }^{37} \mathrm{Ar}_{\mathrm{a}}}{{ }^{39} \mathrm{Ar}_{\mathrm{K}}}$ & $\frac{{ }^{40} \mathrm{Ar}}{36 \mathrm{Ar}}$ & Age $\pm 2 \sigma$ & vol ${ }^{39} A \mathbf{r}_{K}$ & $\frac{{ }^{40} \mathrm{~A} \mathrm{r}^{*}}{{ }^{39} \mathrm{~A} \mathrm{r}_{\mathrm{K}}}$ & vol ${ }^{36} \mathrm{~A} r$ \\
\hline \multicolumn{7}{|c|}{ Type l crystals $\quad J$ value $=0.002093$} \\
\hline $\mathrm{a} 2$ & $1.029 \mathrm{e}-2$ & $3.860 \mathrm{e} 3$ & $4.36 \pm 0.05$ & $1.9327 \mathrm{e}-09$ & 1.15668 & $6.2724 \mathrm{e}-13$ \\
\hline a3 & $0.758 \mathrm{e}-2$ & $8.524 \mathrm{e} 3$ & $4.38 \pm 0.05$ & $2.1913 \mathrm{e}-09$ & 1.15991 & $3.0886 \mathrm{e}-13$ \\
\hline a9 & $1.120 \mathrm{e}-2$ & $12.49 \mathrm{e} 3$ & $4.38 \pm 0.04$ & $1.9265 \mathrm{e}-09$ & 1.16057 & $1.8329 \mathrm{e}-13$ \\
\hline alo & $0.564 \mathrm{e}-2$ & $4.504 \mathrm{e} 3$ & $4.3 \pm 0.1$ & $4.1803 \mathrm{e}-10$ & 1.13943 & $1.1316 \mathrm{e}-13$ \\
\hline a11 & $0.692 \mathrm{e} 2$ & $10.02 \mathrm{e} 3$ & $4.42 \pm 0.08$ & $1.1914 \mathrm{e}-09$ & 1.706 & $1.4158 \mathrm{e}-13$ \\
\hline a4 & $2.394 \mathrm{e}-2$ & $6.425 \mathrm{e} 3$ & $4.39 \pm 0.04$ & $2.3009 \mathrm{e}-09$ & 1.16408 & $4.3694 \mathrm{e}-13$ \\
\hline a16 & $0.625 \mathrm{e}-2$ & $7.922 \mathrm{e} 3$ & $4.43 \pm 0.09$ & $4.4839 \mathrm{e}-10$ & 1.17392 & $6.9016 \mathrm{e}-14$ \\
\hline \multicolumn{7}{|c|}{ avg. weighted mean age $4.38 \pm 0.04$} \\
\hline \multicolumn{7}{|c|}{ Type 2 crystals $J$} \\
\hline as & $0.515 \mathrm{e}-2$ & $1.867 \mathrm{e} 3$ & $4.73 \pm 0.03$ & $3.0904 \mathrm{e}-09$ & 1.2383 & $2.0828 \mathrm{e}-13$ \\
\hline a6 & $0.727 \mathrm{e}-2$ & $30.94 \mathrm{e} 3$ & $4.6 \pm 0.1$ & $4.4269 \mathrm{e}-10$ & 1.20644 & $1.7425 \mathrm{e}-13$ \\
\hline al2 & $1.057 \mathrm{e}-2$ & $4.87 \mathrm{le} 3$ & $4.50 \pm 0.06$ & $1.0579 \mathrm{e}-09$ & 1.1789 & $2.7254 \mathrm{e}-13$ \\
\hline a19 & $1.122 \mathrm{e}-2$ & $4.046 \mathrm{e} 3$ & $4.5 \pm 0.1$ & $6.0023 \mathrm{e}-10$ & 1.16426 & $1.8633 e-13$ \\
\hline a26 & $0.585 \mathrm{e}-2$ & $12.85 \mathrm{e} 3$ & $4.47 \pm 0.05$ & $1.8975 \mathrm{e}-09$ & 1.17069 & $1.7689 \mathrm{e}-13$ \\
\hline a 27 & $0.715 e-2$ & $3.857 \mathrm{e} 3$ & $4.48 \pm 0.04$ & $3.4756 c-09$ & 1.17145 & $1.143 c-12$ \\
\hline \multicolumn{7}{|c|}{ avg. weighted mean age $4.56 \pm 0.05$} \\
\hline \multicolumn{7}{|c|}{ Type 5 crystals $J$} \\
\hline a28 & $1.453 \mathrm{e}-2$ & $2.624 \mathrm{e} 3$ & $4.4 \pm 0.1$ & $5.932 \mathrm{e} \cdot 10$ & 1.12586 & $2.8683 e-13$ \\
\hline a34 & $1.177 \mathrm{e}-2$ & $4.736 \mathrm{e} 3$ & $4.52 \pm 0.04$ & $2.2029 \mathrm{e}-09$ & 1.16662 & $5.7876 \mathrm{e} \cdot 13$ \\
\hline a35 & $1.106 \mathrm{e}-2$ & $0.3923 \mathrm{e} 3$ & $5.1 \pm 0.2$ & $4.7776 \mathrm{e}-09$ & $1.3178 \mathrm{I}$ & $6.5034 \mathrm{e}-11$ \\
\hline a 48 & $0.485 \mathrm{e}-2$ & $7.162 \mathrm{e} 3$ & $4.46 \pm 0.03$ & $5.4717 \mathrm{e}-09$ & 1.15085 & $9.1704 \mathrm{e}-13$ \\
\hline a41 & $0.657 \mathrm{e}-2$ & $6.255 \mathrm{e} 3$ & $4.35 \pm 0.08$ & $5.0929 \mathrm{e}-10$ & 1.12324 & $9.5982 \mathrm{e}-14$ \\
\hline a42 & $0.938 \mathrm{e}-2$ & $0.7549 \mathrm{e} 3$ & $4.50 \pm 0.05$ & $1.8188 \mathrm{e}-09$ & 1.16124 & $4.5978 \mathrm{e}-12$ \\
\hline
\end{tabular}

weighted (by ${ }^{39} \mathrm{Ar}$ ) mean and by determining an isochron age using the YORK (1969) regression method (Table 1). All ages are given with $2 \sigma$ error.

Seven euhedral alkali feldspar crystals, uniform in size and clear (crystal type Type 1), yield ages that are identical within analytical error (Table 1). An integrated age of $4.38 \pm 0.04$ Ma was obtained and is interpreted as the eruption age. This age is somewhat younger than the $4.7 \mathrm{Ma}$ age obtained by K-Ar dating of biotite (BORSI et al., 1967) that has been assumed as the eruption age (FERRARA et al., 1989). Subhedral alkali feldspar crystals, clear (Type 2) or milky white (Type 5), yield a range of ages from within error of the eruption age, $4.35 \pm 0.08 \mathrm{Myr}$, to $5.1 \pm 0.2 \mathrm{Myr}$. Figure 6 presents the ages for each crystal from the three morphological groups analyzed.

\section{STRONTIUM ISOTOPE COMPOSITIONS}

The $\mathrm{Sr}$ isotope data on individual mineral grains, glass, and bulk mineral separates are presented in Table 2 . The initial ${ }^{87} \mathrm{Sr} /{ }^{86} \mathrm{Sr}$ ratios of minerals and the glass have all been age corrected to the eruption age of $4.38 \mathrm{Ma}$ obtained from ${ }^{40} \mathrm{Ar}-{ }^{39} \mathrm{Ar}$ dating, and in the discussion below all ratios are initial ratios. There is a large variation in the calculated initial $\mathrm{Sr}$ isotope composition for all minerals, independent of any uncertainties in the eruption age.

\section{Glass and Alkali Feldspar}

The initial ${ }^{87} \mathrm{Sr} /{ }^{86} \mathrm{Sr}$ of glass from the Group A sample is 0.7247 , significantly more radiogenic than the glass from the Group B sample, with an initial ${ }^{87} \mathrm{Sr} /{ }^{86} \mathrm{Sr}$ of 0.7130 . This is consistent with the findings of FERRARA et al. (1989) and PINARELLI et al. (1989). Individual alkali feldspars from the Group B sample display a range in initial ${ }^{87} \mathrm{Sr} /{ }^{86} \mathrm{Sr}$ of 0.7145 to 0.7184 ; analysis of the bulk separate from a sample from the same location by FERRARA et al. (1989) yielded an initial ratio of 0.7174 . In every case, individual alkali feldspar grains are more radiogenic than the host rhyolite glass $(0.7130)$. Euhedral clear crystals (Type 1) are significantly more radiogenic than the rhyolite glass $(0.7145-0.7175$ vs. 0.7130$)$. Subhedral to anhedral alkali feldspars (Type 3-Type 6) are among the most and the least radiogenic in $\mathrm{Sr}$ of this mineral phase. Thus, there is no obvious relationship between initial ${ }^{87} \mathrm{Sr} /{ }^{86} \mathrm{Sr}$ and alkali feldspar morphology. In addition, individual crystals exhibit variation in $\mathrm{Sr}$ isotope ratios between

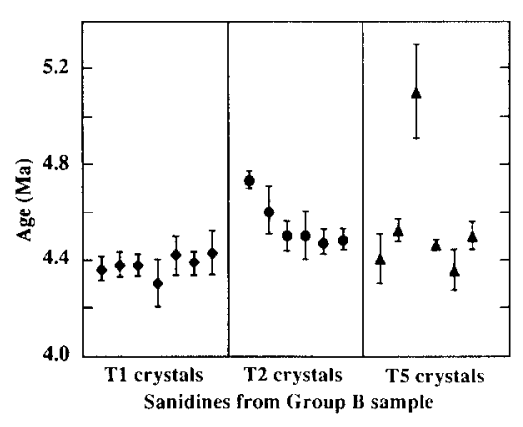

FIG. $6 .{ }^{40} \mathrm{Ar}-{ }^{39} \mathrm{Ar}$ ages for individual alkali feldspar crystals from different crystal morphological groups from Group B: Type 1, euhedral, uniform size, clear crystals; Type 2, subhedral and clear crystals; Type 5, subhedral, milky white crystals. Error bars represent $2 \sigma$ error of age. 
Table 2 Sr isotope ratios, Rb and Sr concentrations for San Vincenzo mineral grains and glass, Group A and B samples

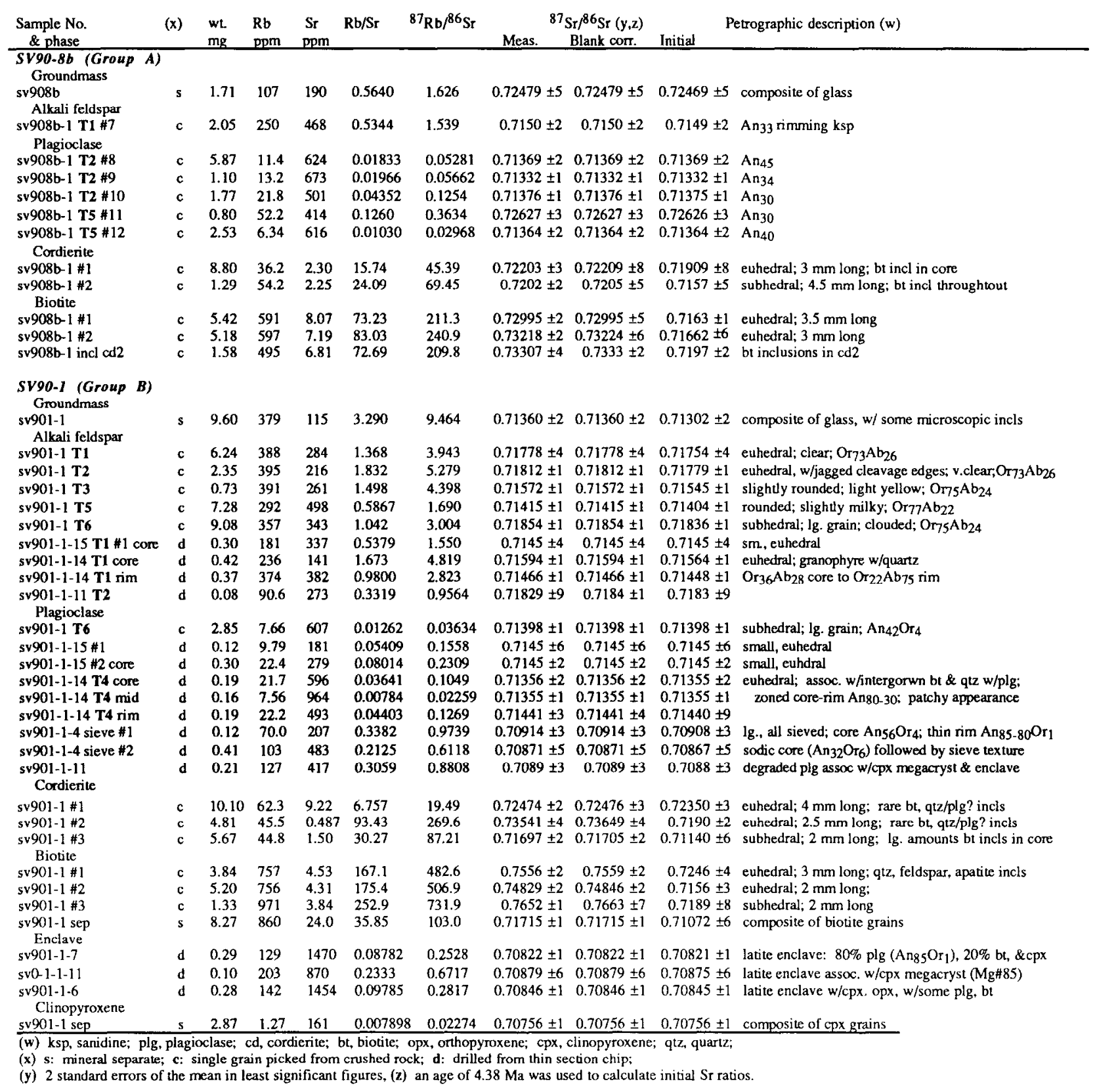

core and rim. A euhedral alkali feldspar grain, zoned from $\mathrm{Or}_{76} \mathrm{Ab}_{22}$ to $\mathrm{Or}_{63} \wedge \mathrm{b}_{36}$, has an initial ${ }^{87} \mathrm{Sr} /{ }^{86} \mathrm{Sr}$ of 0.7156 for the core and 0.7145 for the rim (Figs. 3b, 7). This grain is granophyric with quartz and contains biotite and plagioclase inclusions.

\section{Plagioclase}

The $\mathrm{Sr}$ isotope ratios of plagioclase are correlated with texture. The large plagioclases with extensive sieve zones (Type 4; Fig. 3e) and smaller plagioclase associated with clinopyroxene megacrysts and mafic enclaves (both found in Group B sample only) are relatively unradiogenic, with initial $\mathrm{Sr}$ isotope ratios of $0.7087-0.7091$. All other plagioclases from both samples have higher initial $\mathrm{Sr}$ isotope ratios from $0.7133-0.7149$, a range smaller than that observed for alkali feldspars. An exception to this is a rounded, milky-colored plagioclase in the Group A sample containing radiogenic $\mathrm{Sr}$ (initial ratio of 0.7263 ). Individual plagioclases from the Group A sample are considerably less radiogenic than the enclosing glass ( 0.7247 ) while those from the Group B sample are more radiogenic than the enclosing glass $(0.7130)$. The bulk separate data of FFRRARA et al ( 1989 ) for samples from the same localities, however, indicates that the integrated plagioclase composition (including groundmass-size grains) for both is closer to their respective glass (Fig. 4). Core and rim analyses were obtained from a plagioclase grain from the Group B sample (Figs. 3b, 4). This plagioclase crystal has 


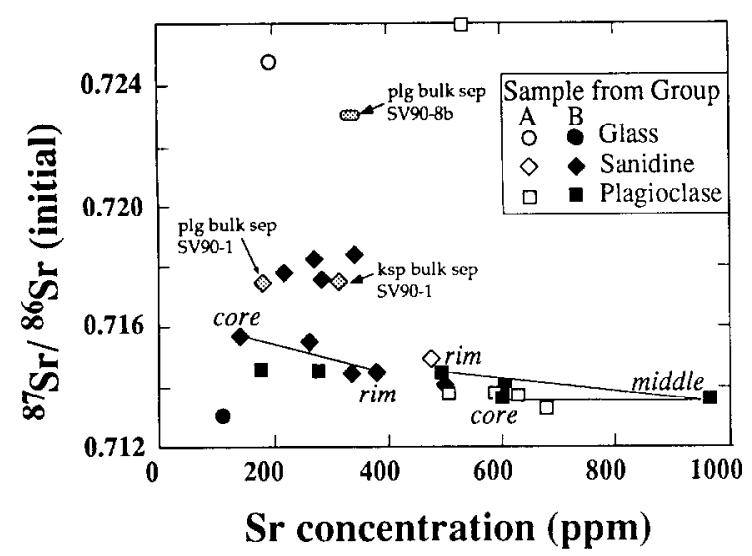

FIG. 7. Initial ${ }^{87} \mathrm{Sr} /{ }^{86} \mathrm{Sr}$ vs. strontium concentration for individual plagioclase and alkali feldspar crystals and glass for Group A (open symbols) and Group B (closed symbols). Core (c), middle ( $\mathrm{m}$ ) and rim ( $r$ ) analyses from a single grain are linked. Analyses of bulk mineral separates for samples from the same localities by FERRARA et al. (1989) also are shown in the light stippled pattern.

patchy extinction, is normally zoned $\left(\mathrm{An}_{80-30}\right)$, and is found in a clot with inter-grown biotite and quartz. The grain is zoned in initial ${ }^{87} \mathrm{Sr} /{ }^{86} \mathrm{Sr}$ from a core of 0.7136 to a more radiogenic rim of 0.7144 (Fig. 7). This zoning is opposite to that found in an alkali feldspar grain located less than $1 \mathrm{~cm}$ away (described above), although their rim $\mathrm{Sr}$ isotopic compositions are the same.

\section{Biotite, Cordierite, and Clinopyroxene}

Individual euhedral biotite crystals analyzed from both samples exhibit a significant range in strontium isotope ratios, from $0.716-0.726$. The biotite separate for the sample from Group B has an initial Sr isotope ratio of 0.7107 , less radiogenic than the enclosing rhyolite glass $(0.7130)$, consistent with the data of FERRARA et al. (1989) for the same location. Individual cordierite crystals also have a wide range in initial strontium isotope ratios $(0.7116-0.7236$, Group B sample; $0.7162-0.7193$, Group A sample). In addition, the analyzed cordierites vary significantly in ${ }^{87} \mathrm{Rb} /{ }^{86} \mathrm{Sr}$ (19.5-270) with no apparent relationship to their ${ }^{87} \mathrm{Sr} /{ }^{86} \mathrm{Sr}$. The clinopyroxene mineral separate is the least radiogenic phase analyzed (0.7076). Whole rock latite enclaves (Group B only) are slightly more radiogenic $(0.7082-0.7088)$ than the clinopyroxene separate $(0.7076)$.

\section{DISCUSSION}

\section{Possible Causes of Variability in ${ }^{40} \mathrm{Ar}-{ }^{39} \mathrm{Ar}$ Ages}

The ${ }^{40} \mathrm{Ar}-{ }^{39} \mathrm{Ar}$ age data for individual alkali feldspars from the Group B sample provide evidence for Ar inhomogeneity in the San Vincenzo magma. The differences between euhedral, clear crystals that give the eruption age $(4.38 \pm 0.04$ $\mathrm{Ma})$ and subhedral crystals that yield somewhat older ages $(4.35 \pm 0.08 \mathrm{Myr}$ to $5.1 \pm 0.2 \mathrm{Myr})$ may result from the incorporation of excess argon during crystallization of alkali feldspar in the rhyolite or reflect the presence of inherited argon in xenocrystic alkali feldspar. Assimilation of K-rich mica schist or localized heating of the adjacent wall rock by the intrusion of mantle-derived magma in the lower region of the magma chamber may have resulted in variations of ${ }^{40} \mathrm{Ar}$ in the magma chamber, with the excess argon incorporated into alkali feldspar phenocrysts during crystallization. The initial ${ }^{40} \mathrm{Ar}$ of a crystal, therefore, would reflect where the crystal grew within the magma chamber. However, a correlation between the presence of excess ${ }^{40} \mathrm{Ar}$, crystal morphology, and ${ }^{87} \mathrm{Sr} /{ }^{86} \mathrm{Sr}$ ratios is predicted by these scenarios but is not observed, and virtually all of the alkali feldspars plot in a cluster near the radiogenic endmember on an isotope correlation diagram (see values in Table 1). Decoupling of argon and strontium diffusion may account for this lack of correlation.

Excess argon also could be incorporated into crystals during the evolution of a volatile phase from the rhyolite magma, such as during magma decompression. The incorporation of vapor by mineral grains may be an important mechanism by which plutonic alkali feldspars retain excess argon and may result in cloudiness, due to the presence of submicroscopic pores (PARSONS et al., 1988; BURGESS et al., 1992). The observation at San Vincenzo of slightly older ${ }^{40} \mathrm{Ar}-{ }^{39} \mathrm{Ar}$ ages from cloudy and subhedral alkali feldspars is consistent with this hypothesis. However, no TEM work has been done to provide direct evidence for this mechanism.

Another possible explanation is that xenocrysts were incorporated during magma migration to the surface. These xenocrysts may not completely degas, resulting in excess ${ }^{40} \mathrm{Ar}$ and an age older than the eruption age. For example, Lo BELLo et al. (1987) found that laser fusion dating of alkali feldspars from a Quaternary trachyte yielded eruption ages for clear, euhedral crystals, whereas ages as old as $330 \mathrm{Ma}$ were obtained from rounded, cloudy grains, interpreted as partially degassed xenocrysts of wall rock incorporated during eruption. Whereas in the San Vincenzo rhyolites, a xenocryst origin from Hercynian basement mica schist for these alkali feldspars is not supported by their euhedral shapes. Furthermore, all the ages of the alkali feldspars are close to the eruption age.

Finally, it is possible that during the migration of the rhyolite magma to the surface, material may have been incorporated from carlier rhyolitic units. This is arguably the most likely explanation since such xenocrysts may retain small amounts of excess ${ }^{40} \mathrm{Ar}$ but have mineral chemistry and strontium isotope ratios indistinguishable from the alkali feldspar phenocrysts (e.g., BogaARD et al., 1987). Furthermore, it is likely that the older rhyolitic units would be hydrothermally altered, leading to cloudiness in the grains.

\section{Possible Causes of Strontium Isotope Disequilibrium}

The chemical and strontium isotope data for individual mineral grains can now be integrated to determine the cause of the $\mathrm{Sr}$ isotope disequilibrium. In this discussion, we use the term phenocryst to denote crystals grown in the rhyolite liquid, while xenocryst will refer to grains derived from wallrock as well as phenocrysts from different magmas that may have been mixed into the rhyolite. Restite refers to unmelted source rock that does not separate from the melt. The restite model, introduced by WHITE and CHAPPELL (1977) and expanded by CHAPPELL et al. (1987), postulates that separation 
of silicic melts from their source region is inetticient and that a large proportion of crystals entrained in granitoids and felsic volcanic rocks are restitc. FERRARA ct al. (1989) argued that the $\mathrm{Sr}$ isotope disequilibrium among mineral phases at San Vincenzo was due to a significant proportion of the crystals being restite. Others have rejected the importance of a restite contribution in felsic igneous rocks (e.g., VERNON, 1983; WALL et al 1987).

One way to rvaluate the possible causes of the isotopic variations is by applying diffusion calculations. Diffusive equilibration will cause mineral grains, whether phenocryst, xenocryst, or restite, to equilibrate with a host liquid. How retentive a given mineral is for a particular chemical species will depend on its residence time, the temperature, and the mineral type. The residence time of a xenocryst may vary from days to $10^{4}$ years, a reasonable estimate of the residence time for most small crustal magma chambers (HUPPERT and SPARKS, 1988). A temperature range of $750^{\circ} \mathrm{C}-850^{\circ} \mathrm{C}$ was chosen as the best estimate of the crystallization temperature of the rhyolite (CLEMENS and WALL, 1981). Diffusion data for strontium in feldspars are currently available only under water-saturated (GILETTI, 1991a,b) or anhydrous conditions (CHERNIAK and WATSON, 1992). The $a_{\text {HzO }}$ of these lavas clearly lies somewhere in between (CLEMENS and WALL, 1981 ), so the available data provide only an upper and lower limit for the proportion of a grain that can equilibrate with the liquid. The calculations shown here are for anhydrous conditions; the shift in percent equilibration due to watersaturated conditions is the same as an upward shift in temperature of $50^{\circ} \mathrm{C}$. Only data obtained under water-saturated conditions are available for biotite and, therefore, the calculations present an upper limit for the proportion of a biotite grain that has equilibrated with the rhyolite liquid (GILETTI, 1991c). Following CRANK, 1975, feldspar crystals are modeled as a sphere of radius $a$ :

$$
\frac{M_{t}}{M_{\alpha}}=1-\frac{6}{\pi^{2}} \sum_{n=0}^{n=\alpha} \frac{1}{n^{2}} \exp \frac{-D n^{2} \pi^{2} t}{a^{2}} ;
$$

while biotite are modeled as a plane infinite sheet with distance $l$ :

$$
\frac{M_{t}}{M_{\infty}}=1-\sum_{n=0}^{n=\infty} \frac{8}{(2 n+1)^{2} \pi^{2}} \exp \left\{\frac{-D(2 n+1)^{2} \pi^{2} t}{4 l^{2}}\right\} .
$$

The liquid strontium isotope composition need not, however, remain constant through time. The ${ }^{87} \mathrm{Sr} /{ }^{86} \mathrm{Sr}$ ratio of the liquid can be modified by $(1)$ in situ decay of ${ }^{87} \mathrm{Rb} /{ }^{86} \mathrm{Sr}$, (2) assimilation, and (3) magma mixing. The first of these is important in producing disequilibrium among feldspars in high $\mathrm{Rb} / \mathrm{Sr}$ rhyolites (e.g., C.HRISTFNSEN and DePAOI O, 1992) but is irrelevant to low $\mathrm{Rb} / \mathrm{Sr}$ rhyolites such as the lavas of San Vincenzo. Assimilation of Hercynian-age basement mica schist, amphibolite, and gneiss (GIANELLI and PuxedDU, 1979) will increase the ${ }^{87} \mathrm{Sr} /{ }^{86} \mathrm{Sr}$ ratio of the rhyolite liquid. Samples of basement rocks from $2 \mathrm{~km}$ depth in the Larderello geothermal fields have a measured ${ }^{87} \mathrm{Sr} /{ }^{86} \mathrm{Sr}$ ratio of $0.7200-0.7336$ (DF. . MORO et al., 1982) ${ }^{\dagger}$ Direct

† These samples are, however, from a region which has undergone extensive hydrothermal alteration over the last $3 \mathrm{Ma}$. This probably has altered the isotope compositions somewhat. evidence for the third mechanism, magma mixing, is given by the latite enclaves. If the liquid strontium isotopic composition changed at a rate too fast to enable diffusive equilibration between mineral grains and the liquid, isotopic disequilibrium would be observed hetween core and rim, early and late grown grains, and between grains and the glass.

\section{Alkali feldspar}

Seven euhedral clear alkali feldspars (Type 1 ) all give the same age, interpreted as the eruption age for the Group B sample, yet Type 1 grains analyzed for $\mathrm{Sr}$ isotopes are significantly more radiogenic than the enclosing rhyolite glass (initial ${ }^{87} \mathrm{Sr} /{ }^{86} \mathrm{Sr}$ ratio of $0.7145-0.7175$ vs. 0.7130 ). A restite origin for the Type 1 crystals is not supported by their clear, euhedral textures and, therefore, cannot explain the $\mathrm{Sr}$ isotope disequilibrium between the mineral grain and enclosing glass. Another potential source for the alkali feldspar is the latite. Diffusion calculations indicate that alkali feldspars grains as small as $1 \mathrm{~mm}$ radius would experience virtually no equilibration with a changing host rhyolite liquid at $750^{\circ} \mathrm{C}$ over $10^{4}$ years; at $850^{\circ} \mathrm{C}$, only $55 \%$ of an alkali feldspar will equilibrate with the melt (Fig. 8). Thus, an $1 \mathrm{~mm}$ radius alkali feldspar xenocryst with an original strontium isotope composition of 0.7085 (e.g., average of the latite) will only change to 0.7132 ( $55 \%$ equilibration) after $10^{4}$ year residence in a melt of composition 0.7180 at $850^{\circ} \mathrm{C}$, the maximum temperature indicated for the rhyolite. At lower temperatures for the rhyolite, a lower proportion of the grain will be able to equilibrate. Likewise, early grown alkali feldspars also will be unable to fully equilibrate with a rhyolitic liquid of changing isotopic composition. What these calculations clearly demonstrate is that the ${ }^{87} \mathrm{Sr} /{ }^{86} \mathrm{Sr}$ ratio of early alkali feldspar phases will not completely reflect changes in the liquid isotopic composition, such as by mixing with the latite or by assimilation; instead, they will retain a distinct strontium isotope composition, as is observed.

\section{Plagioclase}

Several characteristics found in the plagioclase have been attributed to a restite origin, such as anorthitic cores and

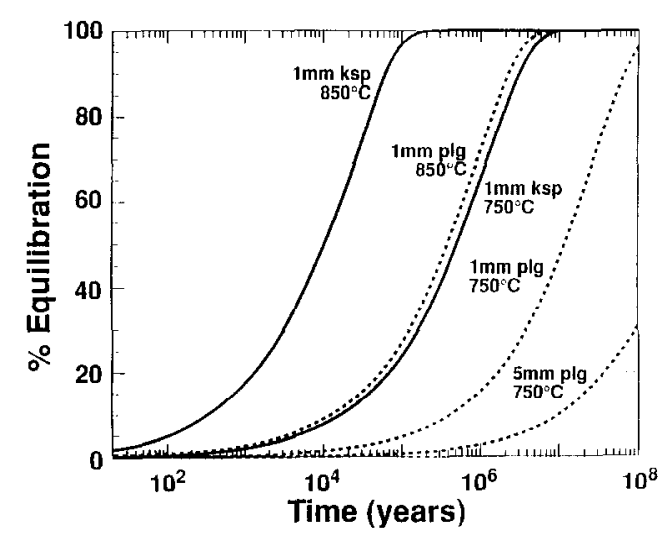

FIG. 8. Calculated percent equilibration curves for $\mathrm{Sr}$ tracer diffusion in plagioclase (dotted line) and alkali feldspar (solid line) at $750^{\circ} \mathrm{C}$ and $850^{\circ} \mathrm{C}$ for $1 \mathrm{~mm}$ and $5 \mathrm{~mm}$ radius grains. 
clots with mafic mincrals (CHAPPELL et al., 1987). While a restite origin for some anorthitic cores is possible, calcic compositions are not restricted to cores. In several cases, the plagioclase composition grown immediately after a sieve zone is anorthitic. For instance, in one grain the entire core has a sieve texture; crystallization following this is zoned from $\mathrm{An}_{83}$ to a rim of $\mathrm{An}_{31}$. The presence of some anorthitic compositions is, therefore, probably due to some other disequilibrium process occurring in the rhyolite. In addition, a restite origin cannot explain the wide variability observed in rims of euhedral plagioclase and groundmass plagioclase. Sieve zones in plagioclase is another texture often interpreted as indicating a restite origin (CHAPPELL et al. 1987). However, these textures are also commonly described in andesites and have been interpreted as resulting from magma mixing or recharge processes in open-systems, or from resorption of early magmatic phases in closed-systems (e.g., HIBBARD, 1981; NiXON and PeARCE, 1987; STAMATElopoulou-SEYMOUR et al., 1990; SINGER et al., 1992). In the lavas from San Vincenzo, normal zonation is found preceding and subsequent to sieve zones, inconsistent with a restite origin. While some plagioclase cores may be restite, a significant role is not supported.

Calculations similar to those performed above for alkali feldspar indicate that a $1 \mathrm{~mm}$ plagioclase xenocryst mixed into the rhyolite from the latite will only change to 0.7099 after $10^{4}$ years at $850^{\circ} \mathrm{C}$, and not the observed $0.7133-0.7149$. Thus, a latite source for the plagioclase is likewise not indicated. An exception appears to be large plagioclase grains (up to $5 \mathrm{~mm}$ radius) characterized by extensive sieve textures, anorthic rims, and unradiogenic $\mathrm{Sr}(0.709)$. These grains, however, make up less than one percent of the population. As demonstrated for alkali feldspar phenocrysts, plagioclase phenocrysts can retain their strontium isotope composition in a melt of changing isotopic composition (Fig. 8). Grains as small as $1 \mathrm{~mm}$ radius would experience virtually no equilibration with the liquid at $750^{\circ} \mathrm{C}$ while at $850^{\circ} \mathrm{C}$ only $5 \%$ will equilibrate with the melt over $10^{4}$ years. Thus, as with the alkali feldspar, the plagioclase population is believed to represent crystal growth in a melt of changing isotopic composition. A significant restite population is not indicated.

\section{Biotite}

FERRARA et al. (1989) suggested two sources for the isotopic disequilibrium in the biotite population: a predominantly restite fraction, with some biotites mixed into the rhyolite along with the latite. The diffusivity of $\mathrm{Sr}$ in biotite at magmatic temperatures is relatively high (GILETTI, 1991), resulting in rapid equilibration between biotite and the host liquid. In order for biotite to retain a strontium isotope composition distinct from that of the liquid, the residence time must be extremely short. Restite, by definition, has long residence times (i.e., longer than for phenocrysts) at elevated temperatures; this ensures that restite biotite will be in $\mathrm{Sr}$ isotope equilibrium with the melt (GILETTI, 1991). The wide range in initial $\mathrm{Sr}$ ratio $(0.7168-0.7259)$ in individual biotite grains, therefore, cannot be attributed to restite. For temperatures $>750^{\circ} \mathrm{C}$, virtually $100 \%$ of a $5 \mathrm{~mm}$ long grain of biotite ( size of biotites individually analyzed for $\mathrm{Sr}$ isotopes) will equilibrate with a $\mathrm{H}_{2} \mathrm{O}$-saturated melt after $10^{4}$ years, whereas a $1 \mathrm{~mm}$ biotite grain will equilibrate at temperatures $>750^{\circ} \mathrm{C}$ in $10^{3}$ years. Xenocrysts with a much shorter residence time (e.g., on the order of days to hundreds of years) in the melt can retain some of their original $\mathrm{Sr}$ signature. However, the biotites analyzed were mostly large, euhedral, hexagonal books, inconsistent with an origin from Hercynian basement rocks and supporting a phenocryst origin. The relatively radiogenic strontium isotopic composition of some of the larger biotites relative to the enclosing glass may have resulted from rapid changes to the rhyolite liquid immediately prior to eruption. While small, groundmass biotite will be able to equilibrate with the new liquid composition, large grains may only partially equilibrate. However, the biotite bulk separates and some of the individual grains are less radiogenic than the enclosing glasses (Table 2; FERRARA et al., 1989). A latite source for some biotites is not supported by petrography. The magnesian biotites, found only in the enclaves and associated with pyroxenes, are a very minor proportion of the population and are not found as individual grains in the rhyolite. One possible explanation is that the finest biotite grains were precipitated from the latite. These grains were able to equilibrate their major element chemistry with the rhyolite liquid while failing to equilibrate strontium isotopic composition. Since Sr does not partition favorably into biotite, it will re-equilibrate slowly. This explanation is supported by the higher strontium concentration of the bulk separate relative to the large single grains in the Group B sample, consistent with partitioning from a high $\mathrm{Sr}$ liquid such as the latite.

\section{Cordierite}

The individual cordierite grains analyzed are characterized by variable ${ }^{87} \mathrm{Rb} /{ }^{86} \mathrm{Sr}$. This suggests contamination of the cordierite isotope systematics by diffusion from biotite inclusions in the grain, and precludes a definitive interpretation of the $\mathrm{Sr}$ isotope disequilibrium. However, textures, such as euhedral and cyclic-twinned grains, and experimental evidence support cordierite as a solidus phase in peraluminous melts (CLEMENS and WALL, 1981, 1984) and most cordierite textures in the San Vincenzo lavas are consistent with a magmatic origin (WHITE and CHAPPELL, 1977; CHAPPELL et al., 1987; WALL et al., 1987). Cordierites that are characterized by ovoid shapes and cores containing inclusions of sillimanite, spinel, and/or biotite may be restites or xenocrysts (e.g., WHITE and CHAPPELL, 1977; PHILLIPS et al., 1981; VERNON, 1983; CLEMLNS and WALL, 1984).

\section{Clinopyroxene}

The clinopyroxenes have $\mathrm{Mg}$-rich cores with $\mathrm{Mg}$ numbers that are greater than expected from near-liquidus equilibrium crystallization from the rhyolite or the latite magmas (GROVE et al., 1982; BAKER and EGGLER, 1987) and have compositions similar to basaltic clinopyroxene. The clinopyroxenes, therefore, may be phenocrysts from a more mafic magma, one parental to the latite, that were entrained along with the latite when it was mixed into the rhyolite. The clinopyroxene separate has slightly less radiogenic Sr than the latite. Because 
diffusive equilibration may have occurred between the rhyolite and latite liquid, the initial ${ }^{87} \mathrm{Sr} /{ }^{86} \mathrm{Sr}$ ratio of the clinopyroxenc is believed to be closer to the value of the liquid parental to the latite (BAKER, 1988). The orthopyroxene core compositions are too $\mathrm{Mg}$-rich to have crystallized from the rhyolite but are consistent with crystallization from a liquid of $60 \mathrm{wt} \% \mathrm{SiO}_{2}$, with a $\mathrm{K}_{d} \frac{\mathrm{Fe} / \mathrm{Mg}}{\mathrm{min} / \mathrm{liq}}$ of 0.2 (Grove et al., 1982; BAKER and EGGLER, 1987).

\section{Model for San Vincenzo}

The $\mathrm{Sr}$ isotope disequilibria in the San Vincenzo rhyolites can be understood in terms of crystal growth in a liquid of changing isotopic composition. The diffusion calculations clearly demonstrate that alkali feldspar and plagioclase will not fully equilibrate with the host liquid over the time scales of small crustal magma chambers. Furthermore, the isotope results for the individual mineral grains in conjunction with mineral chemistry data indicate that restite does not form a significant portion of any mineral faction. The difference between the $\mathrm{Sr}$ isotope data we have obtained for individual mineral grains and bulk mineral separate data lies in the latter being a combination of early- and late-grown phenocrysts as well as groundmass grains.

To this point we have confined our discussion to two localities, sample 1 from Group B and sample $8 \mathrm{~b}$ from Group $A$, but we can now use these results to present a large scale model for San Vincenzo. This model must be able to account for the interaction of latite with only one group of lavas ( $B$; only one enclave has been found in all of Group $A$, this work and others), and be able to describe the isotopic disequilibrium among alkali feldspars and plagioclase as due to crystal growth in a melt of changing isotopic composition in both Group $\mathrm{A}$ and B. It also must support the details of the $\mathrm{Sr}$ isotope systematics and petrography documented here. However, a simple model that must first be considered is if, and how much, of the isotopic disequilibrium is attributable to the mingling of partial melts from diverse source rocks of differing isotopic composition. This may lead to large- and small-scale heterogeneities in the melt isotopic composition and the ${ }^{87} \mathrm{Sr} /{ }^{86} \mathrm{Sr}$ ratio of phenocrysts would reflect the local melt isotopic composition and, therefore, also be heterogeneous. This model can account for the isotopic disequilibrium among some mineral grains; however, it cannot explain the systematic offset between mineral grains and glass. The phenocrysts in all Group A rhyolites are less radiogenic than the enclosing glass while those in all Group B rhyolites are more radingenic (total number of samples is 10 ; this study and FERRARA et al., 1989). It is unlikely that this relationship would occur simply by chance in all locations. While some amount of isotopic heterogeneity in the melt may have been produced by this mechanism, it cannot be the only cause of the major isotopic disequilibrium recorded.

A model that seems more appropriate for San Vincenzo is one in which systematic isotopic heterogeneities in the melt result from the processes of magma mixing and assimilation (Fig. 9a). In this model, the magma chamber is considered to be layered or stratified, with more mafic magma underlying rhyolite magma. The mafic magma is differentiated to latite,
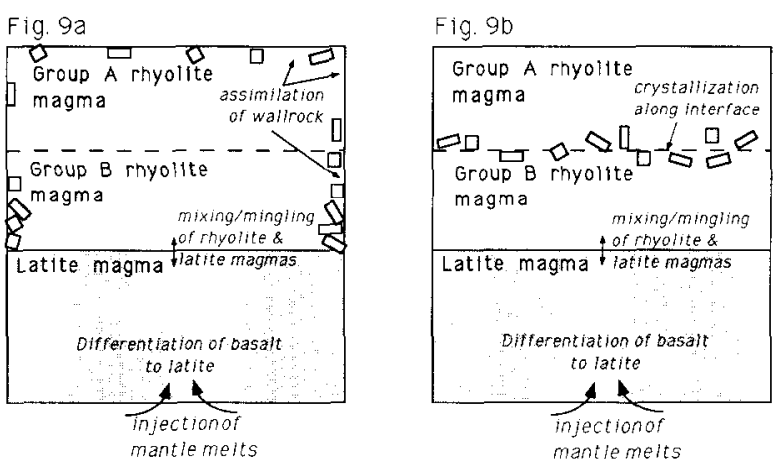

FIG. 9. Two possible models of the San Vincenzo magma chamber. (a) Magma mixing dominates the $\mathrm{Sr}$ isotope evolution of the Group B rhyolites, while assimilation dominates in Group A. (b) Crystallization predominantly occurs in a zone of variably mingled Group $A$ and $B$ rhyolites along the interface between the two. Magma mixing dominates the $\mathrm{Sr}$ isotope evolution of Group B but assimilation is minimal.

which forms the interface with the rhyolite. The ${ }^{87} \mathrm{Sr} /{ }^{86} \mathrm{Sr}$ ratio of the latite is consistent with its parental liquid being of mantle origin since mantle-derived melts in this region are believed to be from enriched mantle with radiogenic $\mathrm{Sr}$ (COX et al., 1976; HAwKESWORTH et al., 1984). The upper portion of the rhyolite magma experiences little to no effect from magma mixing or mingling with the underlying latite magma. However, assimilation of wall rock or partial melts of wall rock with radiogenic $\mathrm{Sr}(0.720-0.734)$ can increase the ${ }^{87} \mathrm{Sr} /{ }^{86} \mathrm{Sr}$ ratio of the liquid. Only the rims of the enclosed phenocrysts would be able to equilibrate with the melt as the residence in the magma chamber probably is less than $10^{4}$ years. Sample 1 of Group A is interpreted as the product of such a magma. Group A lavas are, with one exception, enclave-free and the glass always has more radiogenic Sr than that in the enclosed grains, consistent with this model. The Group B lavas, in contrast, are interpreted as being derived from close to the rhyolite-latite magma interface. These lavas contain chilled latite liquid; clinopyroxene megacrysts, clinopyroxene-orthopyroxene glomerocrysts, orthopyroxeneplagioclase clots, and extensively sieve-textured plagioclase also were mixed into the rhyolite along with the latite liquid. Furthermore, the rhyolite glass contains strontium that is less radiogenic than the enclosed mineral grains. Mixing between rhyolite and latite magmas results in only small changes to the concentrations of major elements, such as silica, compared with dramatic changes in the strontium isotope composition due to the high strontium concentration of the latite liquid. The strontium concentration of the latite is assumed to be at least $1250 \mathrm{ppm}$, the highest concentration found in the enclaves relative to the rhyolite liquid (150-200 ppm). For example, in order to cause a shift in the initial strontium ratio from 0.7183 , the most radiogenic alkali feldspar measured in Group B, to 0.7130 , the strontium isotope ratio of Group B glass, a mixture of 92 percent rhyolite liquid and 8 percent latite is needed. The $\mathrm{SiO}_{2}$ content of the hybrid magma would decrease approximately from 70.0-69.2\%. Furthermore, mixing $8 \%$ latite to a Group A rhyolite is sufficient to produce the differences in whole rock $\mathrm{MgO}$ and $\mathrm{CaO}$ between the groups $\mathrm{A}$ and $\mathrm{B}$. However, only about $1 \%$ 
of the sample from Group B is comingled latite (Appendix Table 3), indicating that some other process also may have occurred. Chemical mixing or diffusion across the boundary may account for the remainder of the chemical modification.

Heat for assimilation may come from the latent heat of crystallization (BOWEN, 1928) or from underlying mafic magmas. There is evidence from the clinopyroxene-orthopyroxene clots for hot $\left(1100^{\circ} \mathrm{C}\right)$ magma associated with the rhyolitic magma. If the mafic magma is the source of heat for assimilation, then the rhyolite closest to the latite-rhyolite interface should experience more assimilation than rhyolite in the upper regions of the magma chamber. However, for this to be consistent with the isotopic data, the Group B lavas would have had to experience a significant amount of mixing with the underlying latite (which has an unradiogenic strontium isotope composition) in addition to the assimilation. This magma must occur for the resulting melt to achieve a strontium isotopic composition less radiogenic than the enclosed mineral grains.

While such models represent a relatively straightforward explanation of the data, there is one observation that suggests an alternative model ( Fig. 9b). The range in the initial strontium isotope compositions is similar for the Group A and B feldspars. This, plus the fact that they are both intermediate between those of the Group A and Group B liquids as recorded in the glasses, suggests that they may have precipitated at an interface between variably mingled Group A and B magmas, i.e., along a thermal boundary layer. Precipitation at this interface would result in phenocrysts with highly variable initial strontium isotope compositions. Disruption of this phenocryst-rich layer during migration of the rhyolite to the surface might result in these grains dominating the phenocryst population of the magma, while the boundary layer liquid would be diluted in the surrounding Group $A$ and Group B magma. Further work is needed to verify the efficacy of this mechanism, and its applicability to other magmatic systems.

\section{CONCLUSIONS}

By obtaining textural and electron microprobe analyses for each of the grains used for isotope analysis, petrologic and isotopic information can be powerfully combined. The San Vincenzo rhyolites exhibit marked $\mathrm{Sr}$ isotope disequilibrium between mineral grains and enclosing glass as well as within individual grains. The mineral chemistry and isotope data indicate that restite does not form a significant portion of the crystalline assemblage and, therefore, cannot be the source of the $\mathrm{Sr}$ isotope disequilibrium. Xenocrysts mixed into the rhyolite from a mafic magma are identified as clinopyroxene megacrysts, clinopyroxene-orthopyroxene clots, orthopyroxene-plagioclase clots, and plagioclase with extensive sieve textures. These grains all have relatively low initial ${ }^{87} \mathrm{Sr} /{ }^{86} \mathrm{Sr}$ ratios. Grains that may be xenocrysts are cordierites with cores containing inclusions of biotite, spinel and sillimanite, and alkali feldspars with excess ${ }^{40} \mathrm{Ar}$. The $\mathrm{Sr}$ isotope disequilibrium in phenocrysts of plagioclase, alkali feldspar, and biotite is attributed to crystal growth in a liquid of changing isotopic composition. The diffusion calculations demonstrate that alkali feldspar and plagioclase will not fully equilibrate with the host liquid over the time scales of small crustal magma chambers. This finding underscores the advantage of micro sampling in complex systems: bulk mineral separates combine early- and late-grown phenocrysts and thus present only an average geochemical signature. Finally, the data can be used to develop and test models for magma dynamics in crustal reservoirs such as stratified magma chambers. In this respect, the observation that Group A and B lavas have similar strontium isotopic compositions in feldspar phenocrysts despite the fact that the $\mathrm{Sr}$ in the host liquids is more and less radiogenic, respectively, may be explacable if phenocrysts are precipitated in a magma mixing zone at the interface between the two melts.

Acknowledgments-G. Poli and A. Peccerillo are thanked for providing organizational support for field work and S. Conticelli and S. Tommasini are thanked for their field assistance and gracious hospitality. We are grateful to E. J. Essene for advice on mineral chemistry and for reviews of this manuscript. Reviews were also provided by J. Morris, S. Esperanca and an anonymous reviewer as well as by R. A. Lange, J. N. Christensen, C. R. Paslick, and J. Tangeman. R. J. Keller and M. W. Johnson are thanked for help with obtaining isotope analyses and C. E. Henderson for assistance with the electron microprobe. This work was inspired by discussions between ANH and G. Ferrara at the workshop on the Geochemistry of Granitoids, Taormina, Italy 1989. This research was supported from NSF grant EAR-90-04133 to ANH and a grant to ANH from the Office of the Vice President, University of Michigan, for developing microsampling methods. Support for field work was provided by G. S. A. Penrose and Scott Turner awards to SNF.

Editorial handling: J. D. Morris

\section{REFERENCES}

ARTH J. G. ( 1976 ) Behavior of trace elements during magmatic processes-a summary of theoretical models and their applications. J. Res. USGS 4, 41-47.

BACON C. R. ( 1986 ) Magmatic inclusions in silicic and intermediate volcanic rocks. J. Geophys. Res. 91, 6091-6112.

BAKER D. R. ( 1988 ) Tracer vs. trace element diffusion: Diffusional decoupling of Sr concentration from $\mathrm{Sr}$ isotope composition. Geochim. Cosmochim. Acta 53, 3015-3023.

BAKER D. R, and EGGLER D. H. (1987) Compositions of anhydrous and hydrous melts coexisting with plagioclase, augite and olivine or low-Ca pyroxene from $1 \mathrm{~atm}$ and $8 \mathrm{kbar}$; application to the volcanic center of Atka. Amer. Mineral. 72, 12-28.

BARBERI F., INNOCENTI F., and MAZZUOLI R. (1967) Contributo alla conoscenza chimico-petrografica e magmatologica delle rocce intrusive, vulcaniche e filoniane del Campigliese (Toscana). $\mathrm{Mem}$. Soc. Geol. It. 6, 643-681.

BARBERI F., INNOCENTI F., and RICCl C. A. (1971) Il magmatismo nella Toscana meridionale. Rend Soc. It. Mineral. Petrol. 27, 169219.

BOGAARD P. V. D. and HALl. C. M. ( 1987$){ }^{40} \mathrm{Ar} /{ }^{39} \mathrm{Ar}$ laser dating of single grains: ages of Quaternary tephra from the east Eifel volcanic field. FRG. Geophys. Res. Lett. 14, 1211-1214.

BORSI S., FERRARA G., and TONGIORGI E. ( 1967 ) Determinazione con il metodo del $\mathrm{K} / \mathrm{Ar}$ delle età delle rocee magmatiche della Toscana. Boll. Soc. Geol. It. 86, 403-410.

Bowen N. L. (1928) The Evolution of Igneous Rocks. Dover Publ. BREARLEY A. J. ( 1987a) A natural example of the disequilibrium breakdown of biotite at high temperature: TEM observations and comparison with experimental kinetic data. Mineral. Mag. 51, 93-106.

BREARLEY A. J. (1987b) An experimental and kinetic study of the breakdown of aluminous biotite at $800^{\circ} \mathrm{C}$ : reaction microstructures and mineral chemistry. Bull. Mineral. 110, 513-532. 
Burgess R., Kelley S. P., Parsons 1., Walker F. D. L., and WARDEN R. H. ( 1992) ${ }^{40} \mathrm{Ar}-{ }^{39} \mathrm{Ar}$ analyses of perthite microstructures and fluid inclusions in alkali feldspars from the Klokken syenite, South Greenland. Earth Planet. Sci. Lett., 109, 147-167.

ChaPpell B. W. and White A. J. R. ( 1974 ) Two contrasting granite types. Pacific Geol. 8, 173-174.

CHAPPEll B. W., White A. J. R., and WYBORN D. (1987) The importance of residual source material (restite) in granite petrogenesis. J. Petrol. 28, 1111-1138.

ChERNiAK D. J. and WATson E. B. (1992) A study of strontium diffusion in $\mathrm{K}$-feldspar, Na-K feldspar and anorthite using Rutherford backscattering spectroscopy. Earth Planet. Sci. Lett. 113, $411-425$.

Christensen J. N. and DePaolo D. J. (1993) Timescales of large volume silicic magma systems: $\mathrm{Sr}$ isotopic systematics of phenocrysts and glass from the Bishop Tuff, Long Valley, California. Contrib. Mineral. Petrol. 113, 100-114.

CLEMENS J. D. and WALL V. J. ( 1981 ) Origin and crystallization of some peraluminous ( S-type) granitic magmas. Canadian Mineral. 19, $111-131$

Clemens J. D. and WAI I. V. I. (1984) Origin and evolution of a peraluminous silicic ignimbrite suite: the Violet Town Volcanics. Contrib. Mineral. Petrol. 88, 354-371.

COX K. G., HAWkesworth C. J., O'Nions R, K., and APPLETON J. D. (1976) Isotopic evidence for the derivation of some Roman region volcanics from anomalously enriched mantle. Contrib. Mineral. Petrol. 56, 173-180.

CRANK J. (1975) The Mathematics of Diffusion. 2nd ed. Clarendon Press.

Davidson J. P., DeSilva S. L., Holden P., and Halliday A. N. (1990) An investigation of small scale disequilibrium in a magmatic inclusion and its more silicic host. J. Geophys. Res. 95, 1766117675 .

Del Moro A., Puxeddu M., Radicati diBrozolo F., and Villa I. M. ( 1982 ) $\mathrm{Rb}-\mathrm{Sr}$ and $\mathrm{K}-\mathrm{Ar}$ ages on minerals at temperatures of $300^{\circ}-400^{\circ} \mathrm{C}$ from deep wells in the Lardarello volcano field (Italy). Contrib. Mineral. Petrol. 81, 340-349.

DUPUY C. and AlleGRE C. J. (1972) Fractionnement K/Rb dans les suites ignimbritiques de Toscane: un example de rejuvenation crustale. Geochim. Cosmochim. Acta 36, 437-458.

FERRARA G. (1969) Rapporti tra la composizione isotopica dello $\mathrm{Sr}$ ed $\mathrm{i}$ fenomeni anatetici nelle rocce della provincia magmatica Toscana. Rend. Soc. It. Mineral. Petrol. 25, 165.

Ferrara G. (1983) Utilizzazione dei dati radiometrici in rocce magmatiche: possibilità e limiti del metodo Rb/Sr. Rend. Soc. It. Mineral. Petrol. 38, 65-72.

Ferrara G.. PETrini R., and Tonarini S. ( 1986 ) S. Vincenzo volcanites (Italy): a Sr-Nd isotopic study. Terra Cognita 6, 200. (abstr.)

Ferrara G., Petrini R., Serri G., and Tonarini S. (1989) Petrology and isotope-geochemistry of San Vincenzo rhyolites ( Tuscany, Italy). Bull. Volcanol. 51, 379-388.

FUHRMAN M. and LINDSLEY D. H. (1988) Ternary-feldspar modeling and thermometry. Amer. Mineral. 68, 201-215.

Gianelli G. and PuXeddu M. (1979) An attempt at classifying the Tuscan Paleozoic: geochemical data. Mem. Soc. Geol. It. 20, 435446.

GiletTı B. J. (199la) Rb and Sr diffusion in alkali feldspars, with implications for cooling histories of rocks. Geochim. Cosmochim. Acta 55, 1331-1343.

Giletti B. J. (1991b) Mg, $\mathrm{Ca}, \mathrm{Sr}$ and $\mathrm{Ba}$ diffusion in plagioclase and $\mathrm{Sr}$ diffusion in micas. $\operatorname{EOS} 72,292$. (abstr.)

GiletTI B. J. (1991c) Diffusion kinetics of $\mathrm{Mg}, \mathrm{Ca}, \mathrm{Sr}$ and $\mathrm{Ba}$ in albite and $\mathrm{Sr}$ in muscovite and biotite. $\operatorname{EOS~72,529.~(abstr.)~}$

Giraud A., Dupuy C., and Dostal J. (1986) Behavior of trace elements during magmatic processes in the crust: application to acidic volcanic rocks of Tuscany (Italy). Chem. Geol. 57, 269288.

GreEN T. H. (1976) Experimental generation of cordierite- or garnetbearing granitic liquids from a pelitic composition. Geology 4, 8588.

Grove T. L., Gerlach D. C., and Sando T. W. (1982) Origin of calc-alkaline series lavas at Medicine Lake Volcano by fractionation. assimilation and mixing. Contrib. Mineral. Petrol. 80, 160182 .
Halliday A. N., Mahood G. A., Holden P., Metz J. M., Demps TER T. J., and DAVIDSON J. P. ( 1989 ) Evidence for long residence times of rhyolitic magma in the Long Valley magmatic system: the isotopic record in precaldera lavas of Glass Mountain. Earth Planet. Sci. Lett. 94, 274-290.

Hawkesworth C. J., Rogers N. W., van Calsteren P. W. C., and MENZIES M. A. ( 1984 ) Mantle enrichment processes. Nature 311, 331-335.

HIBBARD M. J. ( 1981 ) The magma mixing origin of mantled feldspars. Contrib. Mineral. Petrol. 76, 158-170.

HuPPERT H. E. and SPARKS R. S. (1988) The generation of granitic magmas by intrusion of basalt into continental crust. J. Petrol. 29, 599-624.

LE BReton N. and Thompson A. B. (1988) Fluid-absent (dehydration) melting of biotite in metapelites in the early stages of crustal anatexis. Contrib. Mineral. Petrol. 99, 226-237.

LINDSLEY D. H. (1983) Pyroxene thermometry. Amer. Mineral. 68, $177-193$

LINDSLEY D. H. and NEKVASIL H. ( 1989) A ternary feldspar model for all reasons. EOS 70, 506. (abstr.)

Lo Bfi Io P., FFratid G., Hai. C. M., York D., Lavina P., and BERNAT M. ( 1987$){ }^{40} \mathrm{Ar} /{ }^{39} \mathrm{Ar}$ step-heating and laser fusion dating of a Quaternary pumice from Neschers, Massif Central, France: the defeat of xenocrystic contamination. Chem. Geol. 66, 61-71.

LOFGREN G. E. ( 1974) An experimental study of plagioclase crystal morphology: isothermal crystallization. Amer. J. Sci. 274, $243-$ 273.

MaRINelli G. ( 1961 ) Genesi e classificazione delle vulcaniti recenti Toscane. Atti Società Toscanna Scienze Naturali: Serie A 68, 74 116

NiXON G. T. and PEARCE T. H. (1987) Laser-interferometry study of oscillatory zoning in plagioclase: The record of magma mixing and phenocryst recycling in calc-alkaline magma chambers, Iztaccihuatl volcano, Mexico. Amer. Mineral. 72, 1144-1162.

Parsons I., ReX D. C., Guise P., and Halliday A. N. (1988) Argon-loss by alkali feldspars. Geochim. Cosmochim. Acta $\mathbf{5 2}$, 1097-1112.

Peccerillo A., Conticelli S., and Manetti P. (1987) Petrological characteristics and the genesis of the recent magmatism of Southern Tuscany and Northern Latium. Per. Mineral. 56, 157-172.

Phillips J. A., WAll V. J., and Clemens J. D. (1981) Petrology of the Strathbogie Batholith: a cordierite-bearing granite. Canadian Mineral. 19, 47-63.

Pichavant M., Kontak D. I., Rriguet I., Herrara J. V., and CLARKE A. H. ( 1988 ) The Miocene-Pliocene Macusani volcanics, SE Peru II: Geochemistry and origin of a felsic peraluminous magma. Contrib. Mineral. Petrol. 100, 325-338.

Pinarelli L., Poli G.. and Santo A. P. (1989) Geochemical characterization of recent volcanism from the Tuscan magmatic province (Central Italy): The Roccastrada and San Vincenzo centers. Per. Mineral. 58, 67-96.

Poli G., Frey F. A., and Ferrara G. (1984) Geochemical characteristics of the South Tuscany (Italy) volcanic province: Cunstraints on lava petrogenesis. Chem. Geol. 43, 203-221.

Samson S. D. and AlEXANDER E. C. (1987) Calibration of the interlaboratory ${ }^{40} \mathrm{Ar}-{ }^{39} \mathrm{Ar}$ dating standard, MMhb-1. Chem. Geol. 66, 27-34.

SinGER B. S., MEYERS J. D., and Frost C. D. (1992) Mid-Pleistocene lavas from the Seguam volcanic center, central Aleutian arc: Closedsystem fractional crystallization of a basalt to rhyodacite eruptive suite. Contrib. Mineral. Petrol. 110, 87-112.

Stamatelopoulou-Seymour K., Vlassopoulos D., Pearce T. H., and RICE C. (1990) The record of magma chamber processes in plagioclase phenocrysts at Thera Volcano, Aegean Volcanic Arc. Greece. Contrib. Mineral. Petrol. 104, 73-84.

TAYLOR H. P. and TURI B. (1976) High ${ }^{18} \mathrm{O}$ igneous rocks from the Tuscan magmatic province, Italy. Contrib. Mineral. Petrol $\mathbf{5 5}$ 33-54.

VERNON R. H. ( 1983 ) Restite, xenoliths and microgranitoid enclaves in granites. Roval Soc. New South Wales 116, 77-103.

VIELZEUF D. and HollowaY J. R. (1988) Experimental determination of the fluid-absent melting relations in the pelitic system. Contrib. Mineral. Petrol. 98, 257-276

VOLLMER R. (1976) Rb-Sr and U-Th-Pb systematics of alkaline rocks: 
the alkaline rocks from Italy. Geochim. Cosmochim. Acta 40, 283295.

VOLLMER R. (1977) Isotopic evidence for genetic relations between acid and alkaline rocks in Italy. Contrib. Mineral. Petrol. 60, 109118.

Wall V. J., Clemens J. D., and Clarke J. D. (1987) Models for granitoid evolution and source compositions. J. Geol. 95, 731749.

White A. J. R. and ChapPELL B. W. (1977) Ultrametamorphism and granitoid genesis. Tectanophys. 43, 7-22.

White A. J. R. and Chappell. B. W. (1988) Some supracrustal (Stype) granites of the Lachlan fold belt. Trans. Roy. Soc. Edinburgh 79, 169-181.

Wyborn D., Chappell B. W., and Johnston R. M. (1981) Three S-type volcanic suites from the Lachlan fold belt, southeast Australia. J. Geophys. Res. 86, 10335-10348.

YORK D. (1969) Least squares fitting of a straight line with correlated errors. Earth Planet. Sci. Lett. 5, 320-324.

Appendix: Table 1 Modal Data

\begin{tabular}{|c|c|c|c|c|c|c|}
\hline \multirow[b]{3}{*}{$7 \%$} & \multicolumn{3}{|c|}{ Group A Sample } & \\
\hline & (1) & & & (1) & & \\
\hline & 68.8 & & & 41.3 & & \\
\hline euhedral ksp & 0.9 & 31.0 & 2.9 & 4.3 & 30.9 & 7.3 \\
\hline subhedral ksp & 0.3 & 10.3 & 1.0 & 3.9 & 28.1 & 6.6 \\
\hline anhedral ksp & 1.7 & 58.6 & 58.6 & 5.7 & 41.0 & 9.7 \\
\hline euhedral plg & 6.4 & 63.4 & 20.5 & 4.3 & 38.7 & 7.3 \\
\hline subhedral plg & 1.8 & 17.8 & 5.8 & 2.8 & 25.2 & 4.8 \\
\hline anhedral plg & 1.0 & 9.9 & 3.2 & 0.7 & 6.3 & 1.2 \\
\hline plg w/sieve ${ }^{\#}$ & 0.9 & 8.8 & 2.9 & 3.3 & 29.7 & 5.6 \\
\hline euhedral crd & 3.7 & $\overline{100.0}$ & 11.9 & 2.9 & 90.6 & 4.9 \\
\hline ovoid cordierite & 0.0 & 0.0 & 0.0 & 0.3 & 9.4 & 0.5 \\
\hline biotite & 6.6 & 100.0 & 21.2 & 17.2 & 945 & 293 \\
\hline biotite w/oxides & 0.0 & 0.0 & 0.0 & 1.0 & 5.5 & 1.7 \\
\hline clinopyroxene & 0.0 & & 0.0 & 0.6 & & 1.0 \\
\hline latite enclave & 0.0 & & 0.0 & 0.8 & & 1.4 \\
\hline quartz & 2.4 & & 7.7 & 3.3 & & 5.6 \\
\hline groundmass* & 5.5 & & 17.6 & 7.6 & & 12.9 \\
\hline \multicolumn{7}{|c|}{ 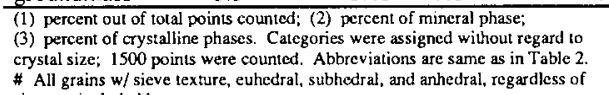 } \\
\hline
\end{tabular}

Appendix: Table 2 Electron

microprobe analyses of selected

glasses

\begin{tabular}{|c|c|c|c|}
\hline & $\begin{array}{l}\text { Group A } \\
\text { matrix }\end{array}$ & $\begin{array}{l}\text { Group B } \\
\text { matrix }\end{array}$ & $\begin{array}{c}\text { Sieve } \\
\text { zone }\end{array}$ \\
\hline$\overline{\mathrm{SiO}_{2}}$ & 72.92 & 73.69 & 76.01 \\
\hline $\mathrm{TiO}_{2}$ & 0.07 & 0.09 & 0.11 \\
\hline $\mathrm{Al}_{2} \mathrm{O}_{3}$ & 13.50 & 12.64 & 13.24 \\
\hline $\mathrm{FeO}^{*}$ & 1.00 & 0.74 & 0.60 \\
\hline $\mathrm{MnO}$ & 0.05 & b.d. & 0.09 \\
\hline $\mathrm{MgO}$ & 0.12 & 0.10 & 0.09 \\
\hline $\mathrm{CaO}$ & 0.51 & 0.53 & 1.54 \\
\hline $\mathrm{BaO}$ & 0.04 & b.d. & b.d. \\
\hline $\mathrm{Na}_{2} \mathrm{O}$ & 3.06 & 2.51 & 1.79 \\
\hline $\mathrm{K}_{2} \mathrm{O}$ & 5.47 & 5.23 & 3.71 \\
\hline Cl & b.d. & 0.02 & 0.02 \\
\hline $\mathrm{F}$ & 0.09 & b.d. & 0.09 \\
\hline $\mathrm{P}_{2} \mathrm{O}_{5}$ & 0.19 & 0.05 & b.d. \\
\hline Total & 97.58 & 95.63 & 97.45 \\
\hline \multicolumn{4}{|c|}{ norm wt\% } \\
\hline $\mathrm{Qz}$ & 34.58 & 39.62 & 49.26 \\
\hline c. & 2.32 & 2.10 & 3.58 \\
\hline Or & 33.26 & 32.32 & 22.55 \\
\hline$A b$ & 26.69 & 22.21 & 15.58 \\
\hline An & 0.86 & 2.41 & 7.86 \\
\hline En & 0.31 & 0.26 & 0.23 \\
\hline Fs & 0.33 & 0.11 & 0.21 \\
\hline $\mathrm{Mt}$ & 0.91 & 0.68 & 0.54 \\
\hline II & 0.14 & 0.18 & 0.20 \\
\hline Ap & 0.44 & 0.12 & 0.00 \\
\hline$F^{r}$ & 0.16 & 0.00 & 0.00 \\
\hline
\end{tabular}

Appendix: Tahle 3 Electron microprobe analyses of selected biotites

\begin{tabular}{|c|c|c|c|c|c|c|c|c|}
\hline Sample & $1-1 \# 32$ & 1-2\#11 & $1-2 \# 34$ & $1-1 \# 6$ & $1-5-\# 19$ & $1-1 \# 9$ & $1-1 \# 2$ & $1-11 \# 2$ \\
\hline wt $\%$ oxide & & & & & & & & \\
\hline $\mathrm{SiO}_{2}$ & 35.14 & 34.19 & 34.33 & 35.86 & 33.35 & 36.96 & 35.26 & 37.0 \\
\hline $\mathrm{O}_{2}$ & 3.79 & 4.19 & 3.65 & 5.75 & 3.81 & 3.99 & 5.65 & \\
\hline $\mathrm{l}_{2} \mathrm{O}_{3}$ & 16.24 & 17.36 & 17.05 & 16.24 & 16.47 & 14.76 & 14.18 & 14.3 \\
\hline${ }_{2} \mathrm{O}_{3}$ & b.d. & 0.03 & b.d. & 0.12 & 0.13 & b.d. & 0.07 & 0.1 \\
\hline $\mathrm{FeO}^{*}$ & 18.28 & 20.71 & 20.10 & 16.63 & 20.88 & 12.02 & 17.12 & 13.2 \\
\hline no & 0.17 & 0.1 & 0.16 & b.d. & 0.07 & 0.05 & 0.07 & 0.2 \\
\hline $\mathrm{gO}$ & 10.22 & 8.79 & 9.60 & 11.21 & 9.12 & 16.83 & 11.93 & 16.4 \\
\hline $\mathrm{OO}$ & 0.32 & 0.1 & 0.17 & 0.29 & 0.07 & 0.34 & 1.16 & 0.5 \\
\hline . & 0.05 & 0.03 & & 0.03 & b.d. & 0.07 & 0.0 & 0.0 \\
\hline${ }_{2} \mathrm{O}$ & 0.46 & 0.52 & 0.4 & 0.46 & 0.43 & 0.61 & 0.40 & .4 \\
\hline 20 & 8.9 & 8.4 & 8.8 & 9.1 & 9.2 & 8.9 & 8.8 & 9.0 \\
\hline & 1.90 & 2.17 & 1.14 & 1.56 & 2.12 & 1.49 & 1.48 & 1.9 \\
\hline & 0.1 & 0.14 & 0.1 & 0.04 & 0.1 & b.d. & 0.0 & b. \\
\hline $2 \mathrm{O}$ & 1.70 & & 2. & & & 2.57 & & 2.4 \\
\hline$=\mathrm{F}, \mathrm{Cl}$ & -0.83 & -0.94 & -0.51 & -0.6 & -0.92 & -0.63 & -0.63 & -0.8 \\
\hline Total & 96.58 & 97.66 & 97.5 & 98.4 & 96.82 & 98.04 & 97.54 & 98.2 \\
\hline \multicolumn{9}{|l|}{ ions } \\
\hline$S i$ & 5.60 & 5.42 & 5.44 & 5.58 & 5.38 & 5.59 & 5.58 & 5.6 \\
\hline jiv & 2.4 & & & 2.43 & 2.62 & 2.41 & 2.42 & \\
\hline $\mathrm{Al}^{\mathrm{vi}}$ & 0.65 & 0.66 & 0.62 & 0.55 & 0.51 & 0.22 & 0.22 & 0.2 \\
\hline $\mathrm{Ti}$ & 0.45 & 0.50 & 0.44 & 0.67 & 0.46 & 0.45 & 0.67 & 0.3 \\
\hline $\mathrm{Cr}$ & b.d. & 0.00 & b.d. & 0.02 & 0.02 & b.d. & 0.01 & 0.0 \\
\hline $\mathrm{Fe}$ & 2.44 & 2.7 & 2.66 & 2.16 & 2.8 & 1.52 & 2.27 & 1.6 \\
\hline $\mathrm{Mn}$ & 0.02 & 0.0 & 0.02 & & 0.01 & 0.01 & .01 & 0.0 \\
\hline $\lg$ & 2.43 & 2.0 & 2.27 & 2.60 & 2.19 & 3.80 & 2.82 & 3.7 \\
\hline & 0.02 & 0.0 & 0.01 & 0.0 & 0.01 & 0.0 & 0.0 & 0.0 \\
\hline $\mathrm{Ca}$ & 0.0 & 0.0 & & 0.0 & & & & 0.0 \\
\hline a & 0.14 & 0.16 & 0. & 0.14 & 0.14 & 0.1 & 0.12 & 0.1 \\
\hline K & 1.83 & 1.70 & 1.79 & 1.82 & 1.91 & 1.73 & 1.79 & 1.7 \\
\hline A site & 1.97 & & & & & & 1.92 & 1.9 \\
\hline 0 & 20.00 & 20.0 & 20.0 & 20. & 20. & 20. & 20.00 & 20.0 \\
\hline O & 1.20 & & 0.8 & 1.4 & 0.90 & 0.69 & 1.23 & 0.5 \\
\hline & 0.96 & 1.0 & 0. & 0.7 & 1.0 & 0.71 & 0.74 & 0.9 \\
\hline & 0.0 & 0.0 & 0. & 0.0 & 0.0 & b.d. & 0.01 & b.c \\
\hline $\mathrm{OH}$ & 1.81 & 1.91 & 2.52 & 1.74 & 2.00 & 2.59 & 2.02 & 2.5 \\
\hline Gg\# & 50 & 43 & 46 & 55 & 44 & 71 & 55 & \\
\hline
\end{tabular}

1-1\#32 matrix; 1-2\#11 euhedral phenocryst; $1-2 \# 34$ included in plagioclase; $1-1 \# 6$ incl xenocryst cordierite; $l-5 \# 19$ assoc. W/ sillimanite xenocryst; $1-1 \# 9$ with magnetite and plagioclase inclusions; $1-1 \# 2$ assoc. w/ opx-plg clot; $1-11 \# 27$ in latite enclave; $\mathrm{FCO}^{-}$ iron as $\mathrm{FeO}$; b.d., below detection limit; $\mathrm{Mg \#}=\mathrm{Mg} /(\mathrm{Mg}+\mathrm{Fe})$; formula calculated by normalizing to 14 small cations $(\mathrm{Si}, \mathrm{Ti}, \mathrm{Al}, \mathrm{Cr}, \mathrm{Fe}, \mathrm{Mn}$, and $\mathrm{Mg}$ )

\begin{tabular}{|c|c|c|c|c|c|c|}
\hline Sample \# & $\begin{array}{c}1-1 \# 11 \\
\text { core }\end{array}$ & $\begin{array}{c}1-1 \# 11 \\
\text { rim }\end{array}$ & $\begin{array}{c}1-8 \# 23 \\
\text { core }\end{array}$ & $\begin{array}{l}1-5 \# 6 \\
\text { core }\end{array}$ & $\begin{array}{c}1-1 \# 14 \\
\text { core }\end{array}$ & $\begin{array}{c}1-1 \# 14 \\
\text { rim }\end{array}$ \\
\hline \multicolumn{7}{|l|}{ wt $\%$ oxides } \\
\hline $\mathrm{SiO}_{2}$ & 49.83 & 48.97 & 49.40 & 49.52 & 48.52 & 49.38 \\
\hline $\mathrm{TiO}_{2}$ & b.d. & b.d. & b.d. & b.d. & b.d. & b.d. \\
\hline $\mathrm{Al}_{2} \mathrm{O}_{3}$ & 34.95 & 33.39 & 33.96 & 33.64 & 33.43 & 34.03 \\
\hline $\mathrm{FeO}^{*}$ & 9.71 & 13.50 & 9.92 & 10.30 & 11.86 & 10.26 \\
\hline $\mathrm{MnO}$ & 0.14 & 0.25 & 0.26 & 0.25 & 0.37 & 0.34 \\
\hline $\mathrm{MgO}$ & 7.63 & 5.33 & 7.41 & 7.28 & 6.21 & 6.86 \\
\hline $\mathrm{CaO}$ & 0.05 & 0.05 & b.d. & 0.10 & 0.09 & 0.03 \\
\hline $\mathrm{Na}_{2} \mathrm{O}$ & 0.13 & 0.06 & 0.06 & 0.03 & 0.18 & 0.09 \\
\hline $\mathrm{K}_{2} \mathrm{O}$ & 0.12 & 0.13 & 0.16 & 0.09 & 0.60 & 0.26 \\
\hline total & 102.56 & 101.66 & 101.18 & 101.20 & 101.26 & 101.24 \\
\hline \multicolumn{7}{|l|}{ \#ions } \\
\hline $\mathrm{Si}$ & 4.96 & 5.00 & 4.97 & 5.00 & 4.97 & 5.00 \\
\hline $\mathrm{Al}^{\mathrm{iv}}$ & 4.04 & 4.00 & 4.03 & 4.00 & 4.03 & 4.00 \\
\hline Alvi & 0.06 & 0.02 & 0.00 & 0.02 & 0.01 & 0.06 \\
\hline $\mathrm{Ti}$ & b.d. & b.d. & b.d. & b.d. & b.d. & b.d. \\
\hline $\mathrm{Fe}$ & 0.81 & 1.15 & 0.84 & 0.87 & 1.02 & 0.87 \\
\hline $\mathrm{Mn}$ & 0.01 & 0.021 & 0.02 & 0.02 & 0.03 & 0.03 \\
\hline $\mathrm{Mg}$ & 1.13 & 0.81 & 1.11 & 1.01 & 0.95 & 1.04 \\
\hline $\mathrm{Ca}$ & 0.01 & 0.01 & b.d. & 0.01 & 0.01 & 0.00 \\
\hline $\mathrm{Na}$ & 0.02 & 0.01 & 0.01 & 0.01 & 0.04 & 0.02 \\
\hline K & 0.02 & 0.02 & 0.02 & 0.01 & 0.08 & 0.03 \\
\hline \# cations & 11.06 & 11.02 & 11.00 & 10.95 & 11.14 & 11.05 \\
\hline $\mathrm{Mg \#}$ & 58 & 41 & 28 & 56 & 48 & 54 \\
\hline
\end{tabular}
cordierite rimming sillimanite xenocryst; 1.1 14 core, nim. euhedral prism with quartz formula calculated by normalizing to 11 small cations ( $\mathrm{Si}, \mathrm{Al}$, Fe, Mn and Mg). 
S. N. Feldstein et al

Appendix: Table 5 Electron microprobe analyses of selected pyroxenes

\begin{tabular}{|c|c|c|c|c|c|c|c|c|c|c|}
\hline Samples & $\begin{array}{l}1-1 \text {-4 } \\
\text { opx,c }\end{array}$ & $\begin{array}{l}1-1 \# 4 \\
\text { opx,r }\end{array}$ & $\begin{array}{r}1-1+12 \\
\operatorname{cpx}, \mathrm{c}\end{array}$ & $\begin{array}{l}1-1 \# 6 \\
\text { opx,c }\end{array}$ & $\begin{array}{r}1-1 \# 11 \\
\text { cpx,r }\end{array}$ & $\begin{array}{l}1-1 \# 5 \\
\text { opx },\end{array}$ & $\begin{array}{r}1-10 \# 15 \\
\text { cpx,c }\end{array}$ & $\begin{array}{l}1-10 \mathrm{HA} \\
\text { opx,c }\end{array}$ & $\begin{array}{l}1-8 \# 2 \\
c p x, r\end{array}$ & $\begin{array}{r}1-11+55 \\
\operatorname{cox}, \mathrm{c}\end{array}$ \\
\hline \multicolumn{11}{|c|}{ wt\% oxides } \\
\hline $\mathrm{SiO}_{2}$ & 56.25 & 54.52 & 53.48 & 55.91 & 53.20 & 52.66 & 53,54 & 54.93 & 52.98 & 51.94 \\
\hline $\mathrm{TO}_{2}$ & 0.19 & 0.27 & 0.29 & 0.17 & 0.32 & 0.46 & 0.31 & 0.29 & 0.33 & 0.36 \\
\hline $\mathrm{Al}_{2} \mathrm{O}_{3}$ & 1.63 & 1.24 & 2.01 & 1.82 & 2.29 & 0.52 & 1.85 & 1.06 & 1.76 & 2.36 \\
\hline $\mathrm{Cr}_{2} \mathrm{O}_{3}$ & 0.17 & 0.12 & 0.18 & 0.27 & 0.20 & 0.05 & 0.16 & b.d. & 0.57 & 0.72 \\
\hline $\mathrm{Fe}_{2} \mathrm{O}_{3}$ & 0.00 & 0.00 & 0.00 & 0.00 & 0.00 & 0.00 & 0.00 & 0.00 & 0.00 & 1.03 \\
\hline FeO & 12.36 & 18.06 & 5.84 & 10.12 & 5.27 & 27.47 & 6.27 & 14.79 & 3.57 & 2.96 \\
\hline $\mathrm{MnO}$ & 0.31 & 0.35 & 0.20 & 0.26 & 0.19 & 0.87 & 0.24 & 0.33 & 0.04 & 0.11 \\
\hline $\mathrm{MgO}$ & 28.38 & 23.97 & 18.20 & 29.97 & 16.97 & 16.59 & 16.80 & 25.85 & 16.81 & 16.56 \\
\hline $\mathrm{CaO}$ & 1.88 & 1.72 & 18.76 & 1.75 & 20.53 & 1.53 & 19.31 & 1.75 & 22.24 & 22.13 \\
\hline $\mathrm{N}_{2} \mathrm{O}$ & b.d. & b.d. & 0.13 & 0.03 & 0.15 & 0.03 & b.d. & b.d. & 0.25 & 0.32 \\
\hline Total & 101.19 & 100.24 & 99.11 & 100.30 & 99.12 & 100.18 & 98.50 & 99.03 & 98.55 & 98.50 \\
\hline \multicolumn{11}{|l|}{ \#ions } \\
\hline $\mathrm{Si}$ & 1.98 & 2.00 & 1.97 & 1.97 & 1.96 & 2.03 & 2.00 & 2.01 & 1.96 & 1.92 \\
\hline Aliv & 0.02 & 0.00 & 0.03 & 0.03 & 0.04 & 0.00 & 0.00 & 0.00 & 0.04 & 0.08 \\
\hline $\mathrm{Al}^{\mathrm{vi}}$ & 0.05 & 0.05 & 0.05 & 0.04 & 0.06 & 0.02 & 0.08 & 0.05 & 0.04 & 0.03 \\
\hline $\mathrm{Fe}^{+3}$ & 0.00 & 0.00 & 0.00 & 0.00 & 0.00 & 0.00 & 0.00 & 0.00 & 0.00 & 0.03 \\
\hline $\mathrm{Ti}$ & 0.01 & 0.01 & 0.01 & 0.01 & 0.01 & 0.01 & 0.01 & 0.01 & 0.01 & 0.01 \\
\hline $\mathrm{Cr}$ & 0.01 & 0.00 & 0.01 & 0.01 & 0.01 & 0.00 & 0,01 & b.d. & 0.02 & 0.02 \\
\hline $\mathrm{Mg}$ & 1.49 & 1.31 & 1.00 & 1.57 & 0.93 & 0.95 & 0.93 & 1.41 & 0.93 & 0.09 \\
\hline $\mathrm{Fe}^{+2}$ & 0.37 & 0.55 & 0.18 & 0.30 & 0.16 & 0.89 & 0.20 & 0.45 & 0.11 & 0.00 \\
\hline $\mathrm{Mn}$ & 0.01 & 0.01 & 0.01 & 0.01 & 0.01 & 0.03 & 0.01 & 0.01 & 0.00 & 0.91 \\
\hline $\mathrm{Ca}$ & 0.07 & 0.07 & 0.74 & 0.07 & 0.81 & 0.06 & 0.77 & 0.07 & 0.88 & 0.88 \\
\hline $\mathrm{Na}$ & b.d. & b.d. & 0.01 & 0.00 & 0.01 & 0.00 & b.d. & b.d. & 0.02 & 0.02 \\
\hline$n$ & 603 & 603 & 602 & 601 & 6.02 & 605 & 6.05 & 604 & $6 \cap 1$ & 600 \\
\hline Wo & 4 & 3 & 39 & 3 & 43 & 3 & 41 & 4 & 46 & 41 \\
\hline En & 77 & 68 & 52 & 81 & 49 & 50 & 49 & 73 & 48 & 50 \\
\hline Fs & 19 & 29 & 9 & 15 & 8 & 47 & 10 & 23 & 6 & 9 \\
\hline
\end{tabular}

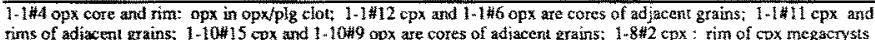

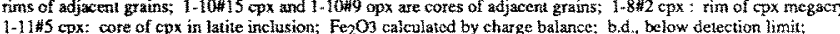

formula calculated on the basis of 4 cations. 